\title{
Mapping and Assessment of Ecosystems Services under the Proposed MAES European Common Framework: Methodological Challenges and Opportunities
}

\author{
Lia Laporta *(D), Tiago Domingos (D) and Cristina Marta-Pedroso
}

MARETEC/LARSyS, Instituto Superior Técnico, Universidade de Lisboa, Av. Rovisco Pais 1, 1049-001 Lisbon, Portugal; tdomingos@tecnico.ulisboa.pt (T.D.); cristina.marta@tecnico.ulisboa.pt (C.M.-P.)

* Correspondence: lia.laporta@tecnico.ulisboa.pt

check for updates

Citation: Laporta, L.; Domingos, T.; Marta-Pedroso, C. Mapping and Assessment of Ecosystems Services under the Proposed MAES European Common Framework:

Methodological Challenges and Opportunities. Land 2021, 10, 1040.

https://doi.org/10.3390/

land 10101040

Academic Editor: Shiliang Liu

Received: 28 July 2021

Accepted: 26 September 2021

Published: 2 October 2021

Publisher's Note: MDPI stays neutral with regard to jurisdictional claims in published maps and institutional affiliations.

Copyright: (c) 2021 by the authors. Licensee MDPI, Basel, Switzerland. This article is an open access article distributed under the terms and conditions of the Creative Commons Attribution (CC BY) license (https:// creativecommons.org/licenses/by/ $4.0 /)$.

\begin{abstract}
The EU Biodiversity Strategy for 2020 was a driving force behind spatially explicit quantifications of Ecosystem Services (ES) in Europe. In Portugal, the MAES initiative (ptMAES-Mapping and Assessment of Ecosystem and their Services) was conducted in 2014 to address Target 2 (Action 5) of the Strategy, namely mapping and assessing ecosystems, ecosystems' condition (EC), and ES. In this study covering the NUTS II Alentejo region, EC was assessed and mapped based on four indicators (soil organic matter, plant and bird diversity, and ecological value of plant communities) and five ES were assessed and mapped (soil protection, carbon sequestration, and fiber/crop/livestock production). Assessments were performed under a multi-tiered approach, ranging from spatialization of statistical data to analytical modeling, based on the most detailed land-use/land-cover cartography available. In this paper, we detail the methodological and analytical framework applied in ptMAES and present its main outcomes. Our goal is to (1) discuss the main methodological challenges encountered to inform future MAES initiatives in Portugal and other member states; and (2) further explore the outcomes of ptMAES by looking into spatial relationships between EC and ES supply. We highlight the advantages of the proposed analytical framework and identify constraints that, among others, limited the number of ES and EC indicators analyzed. We also show that MAES can provide useful insights to landscape planning at the regional scale, for instance, red-flagging areas where ES supply may be unsustainable over time.
\end{abstract}

Keywords: land-use planning; ecosystem services; ecosystem condition; MAES; methodological framework

\section{Introduction}

Ecosystem services (ES) are the benefits humans derive from ecosystems [1], which are categorized into provisioning services (e.g., food production), regulating services (e.g., control of erosion rates), and cultural services (e.g., aesthetic enjoyment of nature) by the Common International Classification of Ecosystem Services (CICES) [2], a mainstream classification within the EU. Although the concept of ES is not exempt from criticism [3], it brings into perspective that humans (and human actions by extension) largely depend on well-functioning ecosystems, emphasizing the need for developing sustainable and resilient interactions between human societies and the natural environment [4]. This imposes new challenges when it comes to landscape planning, calling for an understanding of how human actions across different landscapes can best safeguard well-functioning ecosystems and maximize the services they generate [5]. A core concept in understanding and addressing the sustainability of ES is ecosystem condition [6]. Here, we refer to the ecological condition of ecosystems (EC) as the state of ecological systems, which includes their physical, chemical, and biological characteristics and the processes and interactions that connect them [7]. Biodiversity is commonly understood as one possible indicator of the ecological condition of ecosystems [8,9]. 
Spatially explicit quantifications of ES (i.e., mapping of ES) gained particular prominence in Europe under the EU Biodiversity Strategy for $2020[10]^{1}$. Spatial-based approaches facilitate decision making by providing an efficient way of conveying complex information through visual representation [11] and are valuable in systematic conservation planning to ensure the long-term capacity of ecosystems to provide ES [3]. Despite the increasing number of ES mapping and spatial assessment exercises in the literature, only a small amount have explored Action 5, Target 2 of the EU Biodiversity Strategy for $2020^{2}$ from an integrated scientific perspective, namely by pointing out the relationship between the ecological condition of ecosystems and their service supply capacity under a long-term sustainability perspective [12]. A major challenge lies in the complexity of the relationships between EC and ES [13] and in the fact that these relationships greatly vary depending on the scale of analysis [14,15], which may not coincide with the scale of landscape planning.

In Portugal, the MAES initiative (ptMAES-Mapping and Assessment of Ecosystem and their Services) was set out to address Target 2 of the EU Biodiversity Strategy by taking the challenges imposed by its actions 5 and 7a), namely, "Member States, with the assistance of the Commission, will map and assess the state of ecosystems and their services in their national territory by 2014, assess the economic value of such services, and promote the integration of these values into accounting and reporting systems at EU and national level by 2020". The ptMAES initiative was carried out in 2014 as a regional assessment targeting the NUTS II Alentejo region, which covers about one-third of the total area of mainland Portugal. The goal of ptMAES was to map the dominant ecosystems within the NUTS II Alentejo region ${ }^{3}$ following the European Nature Information System (EUNIS) habitat classification and to map and assess ecosystem's condition and services provided by the agricultural, forest, and agroforestry ecosystems in the region. The study comprised a multi-tiered approach to spatially quantify EC and ES, following the standardized methodological approaches proposed in the MAES guidelines to support the use of ES in planning $[8,16,17]$. With this approach, a set of accurate and defendable methods were selected, intended to deliver outcomes that could better assist decision making aimed at landscape planning under nature conservation goals [18]. Although it presented a pioneering exercise in this regard, the study fell short of providing further clues on the spatial relationships between EC and ES, which may potentially assist the actual integration of ES into landscape planning in the region.

In this paper, we detail the methodological and analytical framework developed in ptMAES to map and assess EC and ES supply, explore spatial relationships between EC and ES supply, and discuss the main challenges and opportunities encountered in order to inform the implementation of future MAES initiatives in Portugal and other member states. As such, the goal of this paper is two-fold. We aimed at developing a methodological reference for national policies furthering the implementation of the EU Biodiversity Strategy to 2020 (namely those concerned with Target 2, Action 5) and of the key actions set out in the EU Biodiversity Strategy to 2030. These national policies include, among others, the Portuguese Nature Conservation and Biodiversity Strategy 2015-2020 and 2020-2030, the National Strategy for Forests up to 2030, and the Commitment for Green Growth 2020/2030. We also aimed at exploring the potentialities of the proposed methodology by further looking into spatial relationships between EC and ES.

\section{Methods}

\subsection{Study Area}

The ptMAES initiative was carried out as a regional study in Alentejo (Figure 1), which presents a typically Mediterranean climate regime [19], dominated by rural landscapes with high potential for tourism [20]. The study focused on the rural landscapes of Alentejo, and as such, only forest, agroforestry, agricultural, and shrubland land use/land cover (LULC) were targeted in the analysis (other LULC were classified as "no data", Figure 1). 


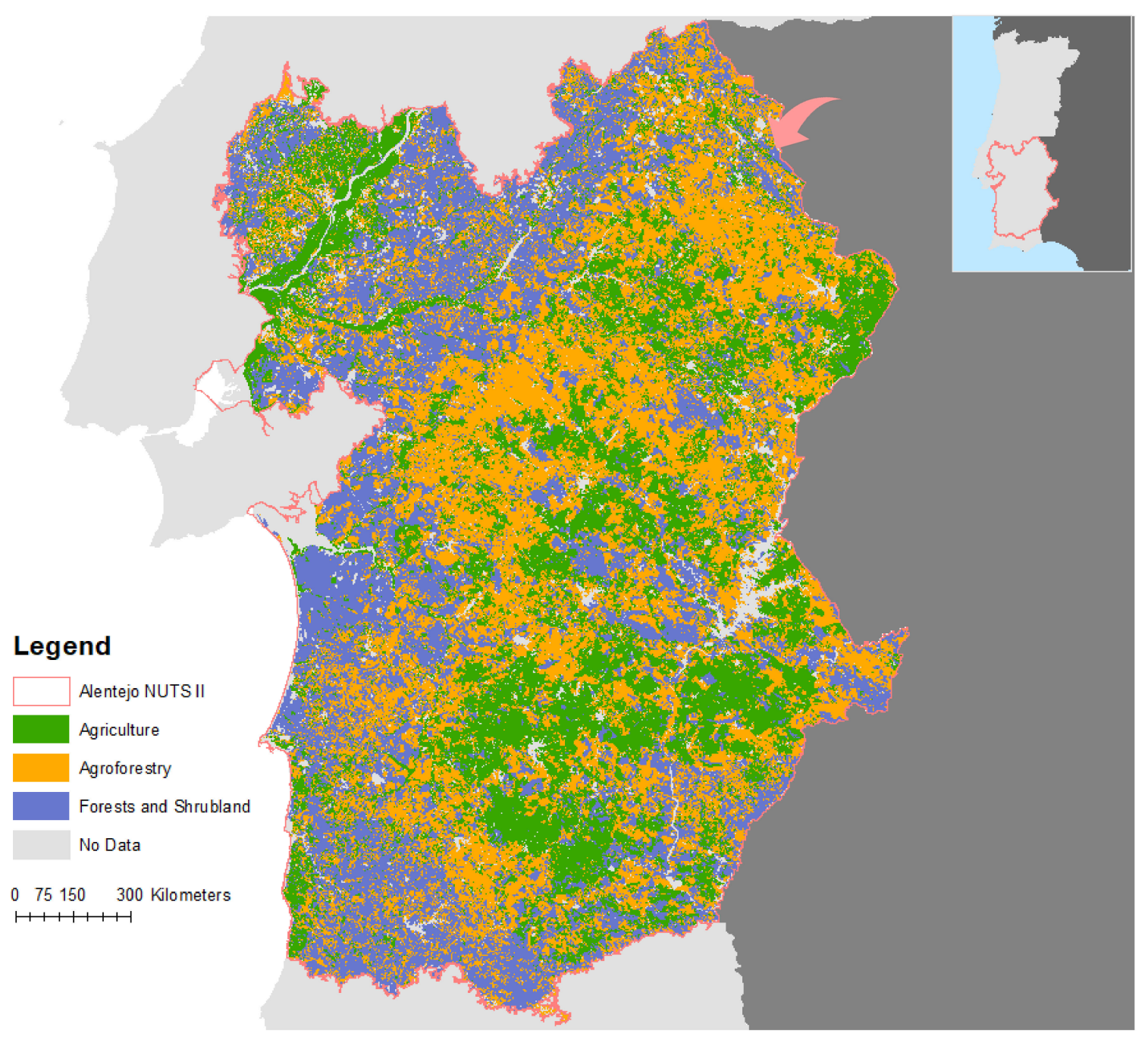

Figure 1. Location and dominant LULC in the study region of Alentejo.

\subsection{Mapping Ecosystems' Condition and Service Supply}

Following MAES guidelines, the methodological framework chosen to map and assess ecosystems' condition and services consists of a multi-tiered approach, combining methods of varying complexity given data availability. The decision on which EC indicators and ES to assess was based on data availability to test the study under the limited time frame usually associated with the implementation period set out in EU strategies/regulations. As such, the selection here presented was supported by discussions with representatives of the National Authority for Nature Conservation (Instituto da Conservação da Natureza e Florestas-ICNF) to accommodate official requirements while accounting for data availability and approved methods to be used under the proposed time frame for the development of this first MAES initiative in Portugal. Figure 2 presents a schematic representation of our approach, and each method is detailed in the following subsections.

All assessments were based on the most detailed LULC cartography publicly available in Portugal, from 2007 (hereinafter COS07), which has a minimum mapping unit of 25 ha. Therefore, the unit of mapping and analysis was the polygons of the COSO7 cartography within the study area that belong to the broad LULC categories shown in Figure 1, namely agriculture, agroforestry, forest, and shrubland $(n=149,013)$. We considered the lowest legend level available for COS07 LULC classes, which reports 59 different LULC classes under agriculture, agroforestry, forest, or shrubland categories (see Supplementary Material Table S1). 


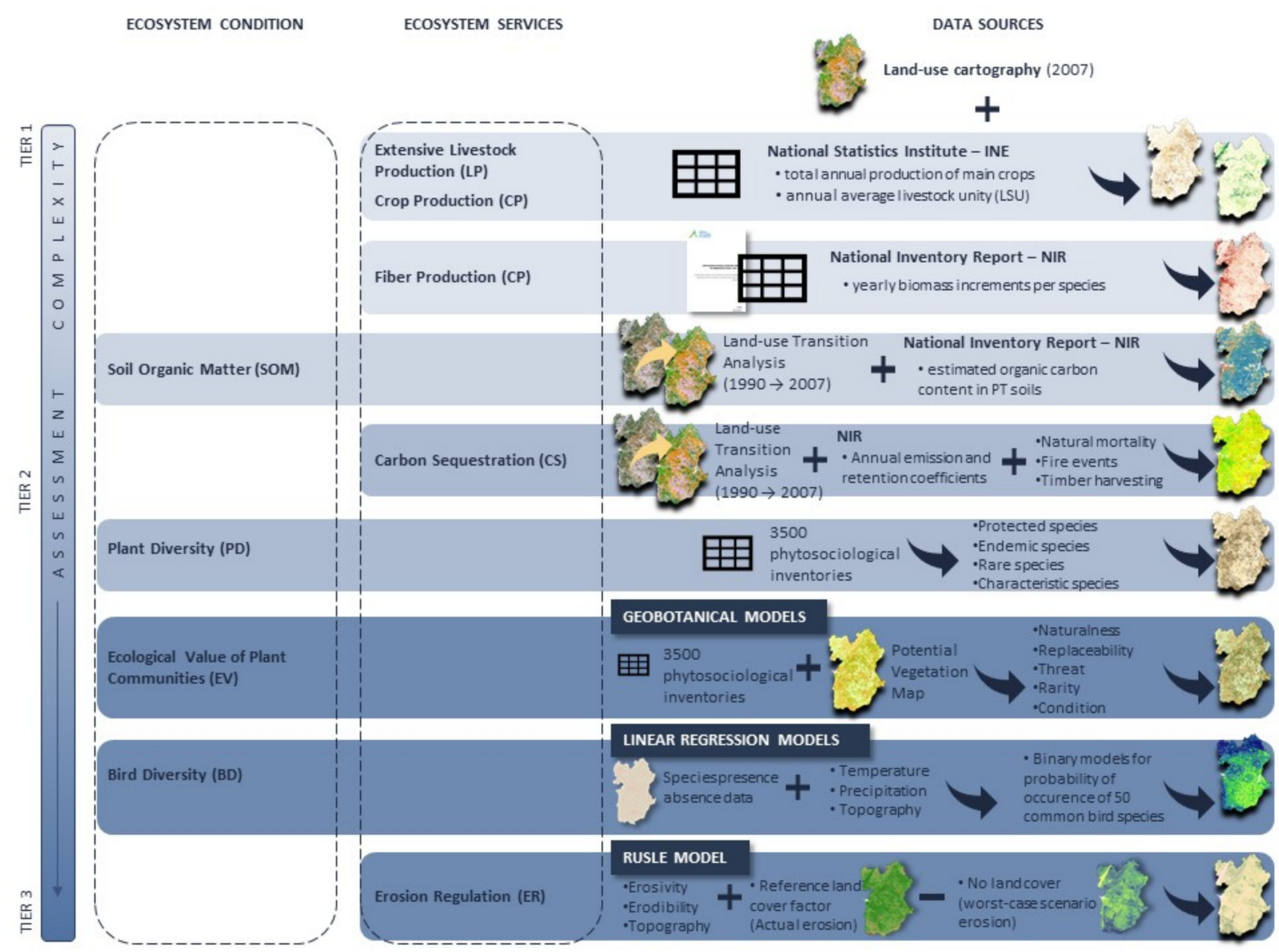

Figure 2. Mapping ecosystems' condition and service supply capacity: methodological overview.

\subsection{Ecosystem Condition (EC)}

Four indicators were considered to assess ecosystems' condition: Soil Organic Matter, Ecological Value of Plant Communities, Plant Diversity, and Bird Diversity. A summary of the selected indicators is presented in Table 1. The methods are further detailed in the following subsections.

Table 1. Final selection of ecosystem condition indicators and a brief description of biophysical mapping methods used.

\begin{tabular}{|c|c|c|}
\hline Selected EC Indicators & Unit & Biophysical Mapping \\
\hline Soil Organic Matter & tonC.ha ${ }^{-1} \cdot$ year $^{-1}$ & $\begin{array}{l}\text { Soil Organic Matter content was assessed based primarily on the information presented in } \\
\text { the National Greenhouse Gases Inventory Report (NIR), according to its land-use } \\
\text { typology (Kyoto Protocol classes) although minor adjustments have been introduced (i.e., } \\
\text { changes in organic matter estimates in areas undergoing land-use change). Soil organic } \\
\text { matter is indicative of the ecological condition of soils, being essential to maintaining soil } \\
\text { ecosystem functions such as stabilization, water infiltration, and conservation of nutrients. }\end{array}$ \\
\hline $\begin{array}{l}\text { Ecological Value of Plant } \\
\text { Communities }\end{array}$ & Semi-Quantitative Score (1 to 5) & $\begin{array}{l}\text { The Ecological Value of Plant Communities represents the mean value of five parameters } \\
\text { (naturalness, replaceability, threat, rarity, and condition), scored from } 1 \text { to } 5 \text {, was } \\
\text { attributed to each of the studied ecosystems (level n). The geobotanical models used, at } \\
\text { the geographical scale in which they were implemented, are indicative of the ecological } \\
\text { condition of ecosystems by providing integrative information on the structural quality, } \\
\text { phytocoenotic integrity, and successional maturity of the present plant communities. }\end{array}$ \\
\hline Plant Diversity & Semi-Quantitative Score (1 to 5) & $\begin{array}{l}\text { Plant Diversity Assessment Assumed that Vegetation Series Maps Provide Information on } \\
\text { the Natural Communities Occurring at Different Locations. it is thus possible to consult } \\
\text { phytosociological tables of these communities and to know their average or characteristic } \\
\text { floristic composition, which reflects species richness and rarity, as well as the presence of } \\
\text { endemic or threatened species. Based on } 3500 \text { phytosociological inventories, } \\
\text { representative of Portuguese natural vegetation, plant diversity was estimated as the } \\
\text { weighted average of four different parameters attributed to each plant community } \\
\text { (presence of protected species, of other endemic species, of other rare species, and of } \\
\text { characteristic species). Plant diversity is an indicator of the ecological condition of } \\
\text { ecosystems by supporting their multi-functionality and resilience. }\end{array}$ \\
\hline
\end{tabular}


Table 1. Cont.

\begin{tabular}{|c|c|c|}
\hline Selected EC Indicators & Unit & Biophysical Mapping \\
\hline Bird Diversity & Semi-Quantitative Score (1 to 5) & $\begin{array}{l}\text { Indicator Assessment was Based on an Extensive and Publicly Available Dataset of } \\
\text { Observation Records (PortugalAves/eBIRD), Used to Obtain a Model (Multiple Logistic } \\
\text { Regression with } 16 \text { Explanatory Variables Related to Land Use, Temperature, Rainfall and } \\
\text { Elevation) that Resulted in a Map with the Potential Distribution of Bird Diversity in the } \\
\text { Study Area. This Indicator is thus given by the estimated number of species in grid cells ( } 2 \\
\times 2 \mathrm{~km} \text { ) covering the study area, which was reclassified into a } 1 \text { (low bird diversity) to } 5 \\
\text { (high bird diversity) scale. as can be noted, this differs from the unit of analysis of the } \\
\text { other indicators (the LULC polygons from COS07), but this issue has been properly } \\
\text { addressed when accounting for spatial relationships. Birds have been widely } \\
\text { acknowledged as indicators of the ecological condition of forests and agroecosystems, } \\
\text { with bird diversity being one possible good measure of the general ecological condition } \\
\text { and overall biodiversity present in an ecosystem. }\end{array}$ \\
\hline
\end{tabular}

\subsubsection{Soil Organic Matter}

To map soil organic matter, we used average organic carbon content present at $0-40 \mathrm{~cm}$ deep soil (Table 2) as obtained from the Portuguese National Greenhouse Gases Inventory Report, hereinafter referred to as NIR (APA, 2004). These average value were estimated based on the results of three international projects, namely ICP Forests grid (1995 and 2005), Biosoil (1999) and LUCAS soil assessment (2009).

Table 2. Average soil organic carbon obtained from APA (2004).

\begin{tabular}{lc}
\hline \multicolumn{1}{c}{ Land-Use Classes } & Average $\mathbf{t C} / \mathbf{h a ~} \mathbf{( 0 - 4 0} \mathbf{~ c m})$ \\
\hline 01. Pinus pinaster & 113 \\
\hline 02. Quercus suber & 66 \\
\hline 03. Eucalyptus spp. & 98 \\
\hline 04. Quercus rotundifolia & 65 \\
\hline 05. Other Quercus spp. & 89 \\
\hline 06. Other broadleaves & 107 \\
\hline 07. Pinus pinea + 08. Other coniferous & 93 \\
\hline 09. Rain-Fed Crops & 59 \\
\hline 10. Irrigated Crops + 11. Rice & 64 \\
\hline 12. Vineyards & 51 \\
\hline 13. Olive & 71 \\
\hline 14. Other Permanent & 56 \\
\hline 15. Grassland & 61 \\
\hline 17. Settlements & 87 \\
\hline 18. Shrubland & 107 \\
\hline
\end{tabular}

The specific land-use classification adopted in the NIR (Kyoto Protocol land-use classes, Table 3) was translated into land-use typologies (COSO7) for harmonization of legends and further use in our study. This harmonization (Supplementary Material Table S4) was later evaluated and approved by NIR authors in a meeting.

We also considered land-use transitions observed (1990 to 2007) to properly adjust the average soil organic carbon content present in each polygon. This means that the soil organic carbon content in polygons that underwent a land-use transition $i \rightarrow j$ is given by the average of the content value of $i$ and $j$. All calculations were performed in ArcGIS (v9.3). 
Table 3. Kyoto Protocol (KP) land-use categories, as defined by the United Nations Framework for Climate Change.

\begin{tabular}{|c|c|c|}
\hline UNFCC Category & KP Land-Use Category & Description \\
\hline \multirow{8}{*}{ Forest Land } & Pinus pinaster & Forests Dominated by Maritime Pine \\
\hline & Quercus suber & Forests Dominated by Cork Oak \\
\hline & Eucalyptus spp. & Forests Dominated by Eucalypt Species \\
\hline & Quercus rotundifolia & Forests Dominated by Holm Oak \\
\hline & Quercus spp. & Forests Dominated by Other Oaks \\
\hline & Other broadleaves & Forests Dominated by any Other Broadleaf Species \\
\hline & Pinus pinea & Forests Dominated by Umbrella Pine \\
\hline & Other Coniferous & Forests Dominated by any Other Coniferous Species \\
\hline \multirow{6}{*}{ Cropland } & Rain-Fed Annual Crops & $\begin{array}{l}\text { Includes All Land Cultivated with Annual Crops without Irrigation } \\
\text { Includes Fallow-Land Integrated Into Crop-Rotations }\end{array}$ \\
\hline & Irrigated Annual Crops & $\begin{array}{c}\text { Includes All Land Cultivated with Annual Crops that is Under Irrigation (Except Rice) and } \\
\text { Greenhouses }\end{array}$ \\
\hline & Rice Paddies & Includes All Land Prepared for Rice Cultivation \\
\hline & Vineyards & Includes All Areas Used for Cultivation of Table and/or Wine Grapes \\
\hline & Olive Groves & Includes All Areas Used for Cultivation of Olea Europea146 \\
\hline & Other Permanent Crops & $\begin{array}{c}\text { Includes All Areas Used for Cultivation of all other Species of Woody Crops, Including Fruit } \\
\text { Orchards147 }\end{array}$ \\
\hline Grassland & All Grasslands & Includes All Lands Covered in Permanent Herbaceous Cover \\
\hline Other land & Shrubland & $\begin{array}{c}\text { Includes All Lands Covered in Woody Vegetation that do not meet the Forest or Permanent Crop } \\
\text { Definitions }\end{array}$ \\
\hline
\end{tabular}

\subsubsection{Ecological Value of Plant Communities \& Plant Diversity}

These two EC indicators were assessed as presented in [21]. The indicator Ecological Value of Plant Communities represents the mean value of five parameters (naturalness, replaceability, threat, rarity, and condition), scored from 1 to 5 , attributed to each of the studied ecosystems (level N). The geobotanical models used, at the geographical scale in which they were implemented, integrated information on the structural quality, phytocoenotic integrity, and successional maturity of plant communities. Further details on the methods used are provided in [21].

The Plant Diversity indicator was assessed assuming that vegetation series maps provide reliable information on the natural communities occurring at different locations. It was thus possible to consult phytosociological tables of these communities and to know their average or characteristic floristic composition, which reflects species richness and rarity, as well as the presence of endemic or threatened species. Based on 3500 phytosociological inventories, representative of Portuguese natural vegetation, plant diversity was estimated as the weighted average of four different parameters attributed to each plant community (presence of protected species, of other endemic species, of other rare species, and of characteristic species). Further information on the methods used is provided in [21].

\subsubsection{Bird Diversity}

As birds are usually referred to as an "indicator" group for several environmental parameters [22], including biodiversity and the condition of ecosystems, bird diversity was also chosen to assess EC. We performed a multiple logistic regression with presence/absence records of farmland and forest bird species and a set of explanatory variables (land-use typology, topography, temperature, and rainfall) (Table 4). See Supplemetary Material Table S1. for aggregation criteria for land-use typologies.

Bird data was collected from an extensive and publicly available dataset of observation records (from the PortugalAves database, which now has been merged into eBIRD https:/ / ebird.org/portugal/home accessed on 1 September 2021). Data processing and validation was required to select only records of true absence/presence and corresponding to a specific temporal scale (2004-2011) close enough to the land use cartography used (2007). This resulted in a final list of 50 species and 15,000 observations (Table 5). Bird observations were recorded in $2 \times 2 \mathrm{~km}$ cells, and thus we applied a $2 \times 2 \mathrm{~km}$ grid over the study area 
and used the cells as the unit of analysis for the Bird Diversity indicator. When comparing with other indicators (see Section 2.5, we integrated the results into the LULC polygons from COS07 by averaging grid cell values within each polygon.

Table 4. Logistic regression variables used to model Bird Diversity.

\begin{tabular}{|c|c|c|c|c|}
\hline Variable & Type & Unit & Temporal Scale & Source \\
\hline $\begin{array}{l}\text { P/A-Presence/Absence of Each Bird } \\
\text { Species }\end{array}$ & Bird data & Factor $(\mathrm{P} / \mathrm{A})$ & 2004-2011 & eBIRD Database \\
\hline tmax-Average Maximum Temperature & \multirow{4}{*}{ Climate and Topography } & ${ }^{\circ} \mathrm{C}$ & \multirow{3}{*}{ 2004-2009 } & \multirow{3}{*}{$\begin{array}{c}\text { MM5 Model (9 km Resolution) } \\
\text { with Krigging (Standard ArcGIS, } \\
1 \mathrm{~km} \text { Pixel) }\end{array}$} \\
\hline tmin-Average Minimum Temperature & & & & \\
\hline rain-Total Rainfall & & $\mathrm{mm}$ & & \\
\hline altm-Average Elevation & & $\mathrm{m}$ & 2009 & $\begin{array}{l}\text { DEM (30 m Resolution) Supplied } \\
\text { by NASA (ASTER Sensor) * }\end{array}$ \\
\hline \multicolumn{5}{|l|}{ flor-Forest } \\
\hline \multicolumn{5}{|l|}{ floa-Open Forest } \\
\hline \multicolumn{5}{|l|}{ agrs-Rainfed Crops } \\
\hline \multicolumn{5}{|l|}{ agrr-Irrigated Crops } \\
\hline \multicolumn{5}{|l|}{ agrp-Permanent Crops } \\
\hline agrm-Mixed Crops & \multirow{7}{*}{ Land-use } & \multirow{7}{*}{ Factor $(\mathrm{P} / \mathrm{A})$} & \multirow{7}{*}{2007} & \multirow{7}{*}{$\begin{array}{c}\text { COS'07 Land-Use Cartography } \\
\text { (See Supplementary Material } \\
\text { Table S1) }\end{array}$} \\
\hline $\begin{array}{l}\text { mont-Montado (Agroforestry } \\
\text { Ecosystems) }\end{array}$ & & & & \\
\hline past-Grasslands & & & & \\
\hline ncul-Shrublands & & & & \\
\hline purb-Urban Settlements & & & & \\
\hline plen-Lakes and Other Water Bodies & & & & \\
\hline plot-Rivers & & & & \\
\hline
\end{tabular}

* http:/ /gdem.ersdac.jspacesystems.or.jp/ (accessed on 1 September 2021).

Table 5. List of bird species and number of records considered for modeling.

\begin{tabular}{|c|c|}
\hline Scientific Name & Number of Records \\
\hline Saxicola torquatus & 264 \\
\hline Sylvia melanocephala & 259 \\
\hline * Sturnus unicolor & 247 \\
\hline Turdus merula & 246 \\
\hline Parus caeruleus & 240 \\
\hline Parus major & 208 \\
\hline Emberiza calandra & 183 \\
\hline Lanius meridionalis & 182 \\
\hline Fringilla coelebs & 175 \\
\hline Buteo buteo & 169 \\
\hline Carduelis carduelis & 167 \\
\hline Passer domesticus & 163 \\
\hline Erithacus rubecula & 157 \\
\hline * Streptopelia decaocto & 149 \\
\hline * Alectoris rufa & 139 \\
\hline Bubulcus ibis & 138 \\
\hline Galerida cristata & 138 \\
\hline Lullula arborea & 138 \\
\hline Carduelis cannabina & 133 \\
\hline
\end{tabular}


Table 5. Cont.

\begin{tabular}{|c|c|}
\hline Scientific Name & Number of Records \\
\hline Galerida theklae & 133 \\
\hline Corous corone & 131 \\
\hline Phylloscopus collybita & 131 \\
\hline Serinus serinus & 128 \\
\hline Oenanthe oenanthe & 125 \\
\hline Cisticola juncidis & 124 \\
\hline Garrulus glandarius & 123 \\
\hline Motacilla alba & 118 \\
\hline * Pica pica & 117 \\
\hline Falco tinnunculus & 116 \\
\hline Upupa epops & 116 \\
\hline Cyanopica cyanus & 115 \\
\hline Carduelis chloris & 112 \\
\hline Columba palumbus & 107 \\
\hline Sylvia atricapilla & 107 \\
\hline Ardea cinerea & 106 \\
\hline Sitta europaea & 104 \\
\hline Certhia brachydactyla & 102 \\
\hline Anthus pratensis & 97 \\
\hline Cettia cetti & 94 \\
\hline Elanus caeruleus & 81 \\
\hline Ficedula hypoleuca & 80 \\
\hline * Troglodytes troglodytes & 80 \\
\hline Hirundo rustica & 78 \\
\hline *Vanellus vanellus & 77 \\
\hline Egretta garzetta & 74 \\
\hline * Anas platyrhynchos & 72 \\
\hline Hirundo daurica & 72 \\
\hline * Turdus philomelos & 67 \\
\hline${ }^{*}$ Tringa ochropus & 65 \\
\hline${ }^{*}$ Dendrocopos major & 62 \\
\hline
\end{tabular}

* Later excluded from analysis, see below.

We ran a separate multiple logistic regression model for each bird species, which resulted in the probability of observation of each species at any given cell of our study area. Ten out of the fifty species were excluded at this point since the models returned significant errors (either false convergency or null convergency, see marked species in Table 5).

All calculations were performed in $\mathrm{R}$ (v. 2.15.13). The multiple logistic regression model was adjusted with the $g l m$ (family = binomial logit) function, with step ( $g l w=$ backwards). AIC (Akaike's information criteria) values were compared before and after stepwise adjustment to ensure the appropriate selection of variables. The Hosmer-Lemeshow goodness-of-fit test [23] was used to compare the log-likelihood of observed and estimated values through the hoslem.test(fitted(backwards)) function (library ResourceSelection). Results for each model are provided in Supplementary Materials (Table S8). We mapped results considering 
that a species would occur in a given cell if the probability returned by our model for that cell was over $50 \%$. This resulted in a map with the potential distribution of bird diversity in the study area. We reclassified our results on a scale from 1 (low diversity) to 5 (high diversity) (Table 6).

Table 6. Bird Diversity Scale.

\begin{tabular}{cc}
\hline Bird Diversity Scale & \# of Species Present $(\boldsymbol{p}>\mathbf{0 . 5})$ \\
\hline 1 & {$[0 ; 5]$} \\
\hline 2 & {$[6 ; 9]$} \\
\hline 3 & {$[10 ; 13]$} \\
\hline 4 & {$[14 ; 17]$} \\
\hline 5 & {$[18 ; \ldots]$} \\
\hline
\end{tabular}

\subsection{Ecosystem Services (ES)}

Five ES were quantified and mapped: control of erosion rates, climate regulation through carbon sequestration, fiber production, crops, and extensive livestock production. A summary of the selected ES, including its designation under the CICES [2] classification system, is presented in Table 7 . The methods are further detailed in the following subsections.

Table 7. Final selection of ES (classification following CICES and specifications for this study) and a brief description of the biophysical mapping methods used.

\begin{tabular}{|c|c|c|c|c|c|}
\hline \multicolumn{5}{|c|}{ Selected ES } & \multirow{3}{*}{$\begin{array}{c}\text { Biophysical Mapping } \\
\text { Description }\end{array}$} \\
\hline \multicolumn{3}{|c|}{ ES Classification Following CICES (v5.1) } & \multicolumn{2}{|c|}{ Specifications } & \\
\hline Section & Section & Class (Code) & ES Designation & Indicator Unit & \\
\hline \multirow{3}{*}{ Provisioning } & \multirow{3}{*}{ Biomass } & $\begin{array}{c}\text { Cultivated Crops } \\
(1.1 .1 .1)\end{array}$ & Crop Production & ton.ha ${ }^{-1} \cdot \mathrm{yr}^{-1}$ & $\begin{array}{l}\text { Crop Production was mapped based on the } \\
\text { total annual production of main cultures } \\
\text { present within the study area. Information } \\
\text { obtained per municipality, based on official } \\
\text { national agriculture statistics (Instituto } \\
\text { Nacional de Estatística, INE). Spatialization } \\
\text { of this information was possible based on the } \\
\text { harmonization of culture classes with LULC } \\
\text { classes. }\end{array}$ \\
\hline & & $\begin{array}{c}\text { Reared Animals and } \\
\text { Their Outputs } \\
(1.1 .1 .2)\end{array}$ & $\begin{array}{c}\text { Extensive Livestock } \\
\text { Production }\end{array}$ & L LU.ha ${ }^{-1} \cdot \mathrm{yr}^{-1}$ & $\begin{array}{l}\text { Extensive Livestock Production was mapped } \\
\text { based on the effective support capacity of } \\
\text { extensive pastures, considering the average } \\
\text { livestock unit (LU) within the study area. } \\
\text { Information obtained per municipality, based } \\
\text { on official national agriculture statistics } \\
\text { (Instituto Nacional de Estatística, INE). } \\
\text { Spatialization of this information was } \\
\text { possible based on the harmonization of } \\
\text { pasture classes with LULC classes }\end{array}$ \\
\hline & & $\begin{array}{l}\text { Fibers and Other } \\
\text { Materials for Direct } \\
\text { Use or Processing } \\
(1.2 .1 .1)\end{array}$ & Fiber Production & $\mathrm{m}^{3} \cdot \mathrm{ha}^{-1} \cdot \mathrm{yr}^{-1}$ & $\begin{array}{l}\text { Fiber Production mapping was based on } \\
\text { yearly biomass increments per species, as } \\
\text { reported in the Portuguese National } \\
\text { Greenhouse Gases Inventory Report (NIR), } \\
\text { According to its land-use typology (Kyoto } \\
\text { Protocol Classes). classes of species } \\
\text { considered were: Pinus pinaster, Pinus pinea, } \\
\text { Quercus spp, Quercus suber, Quercus } \\
\text { rotundifolia, Eucalyptus spp, Mixed } \\
\text { broadleaves forests, and mixed coniferous } \\
\text { forests. average biomass losses due to natural } \\
\text { mortality were discounted. spatialization of } \\
\text { this information was possible based on the } \\
\text { harmonization of kp classes legend with } \\
\text { LULC classes from national cartography. }\end{array}$ \\
\hline
\end{tabular}


Table 7. Cont.

\begin{tabular}{|c|c|c|c|c|c|}
\hline \multicolumn{5}{|c|}{ Selected ES } & \multirow{3}{*}{$\begin{array}{c}\text { Biophysical Mapping } \\
\text { Description }\end{array}$} \\
\hline \multicolumn{3}{|c|}{ ES Classification Following CICES (v5.1) } & \multicolumn{2}{|c|}{ Specifications } & \\
\hline Section & Section & Class (Code) & ES Designation & Indicator Unit & \\
\hline \multirow[t]{2}{*}{ Regulating } & \multirow[t]{2}{*}{$\begin{array}{c}\text { Regulation of } \\
\text { Physical, Chemical, } \\
\text { Biological Conditions }\end{array}$} & $\begin{array}{c}\text { Global Climate } \\
\text { Regulation by } \\
\text { Reduction of } \\
\text { Greenhouse Gas } \\
\text { Concentrations } \\
(2.3 .5 .1)\end{array}$ & $\begin{array}{c}\text { Carbon } \\
\text { Sequestration }\end{array}$ & tonCO $\mathrm{C}_{2} \cdot \mathrm{ha}^{-1} \cdot \mathrm{yr}^{-1}$ & $\begin{array}{l}\text { Carbon Sequestration mapping was based on } \\
\text { input/output balances in biomass (above } \\
\text { and below ground). Annual emission and } \\
\text { retention coefficients for each land-use } \\
\text { change (considering changes observed in a } \\
\text { 17-year period) were estimated based on the } \\
\text { National Inventory Report results (NIR). } \\
\text { Spatialization of this information was } \\
\text { possible based on the harmonization of KP } \\
\text { classes legend with LULC classes from } \\
\text { national cartography. }\end{array}$ \\
\hline & & $\begin{array}{l}\text { Stabilization and } \\
\text { Control of Erosion } \\
\text { Rates (2.2.1.1) }\end{array}$ & $\begin{array}{c}\text { Control of Erosion } \\
\text { Rates }\end{array}$ & ton.ha ${ }^{-1} \cdot \mathrm{yr}^{-1}$ & $\begin{array}{l}\text { Control of Erosion Rates was modeled and } \\
\text { mapped based on the Universal Soil Loss } \\
\text { Equation (USLE), integrated into a GIS } \\
\text { platform, which allowed determining the } \\
\text { difference between erosion rates in the } \\
\text { current scenario (i.e., erosion rates given } \\
\text { actual land cover type) and erosion rates for a } \\
\text { worst-case scenario (considering a maximum } \\
\text { erosion cover type), as first suggested by [24] }\end{array}$ \\
\hline
\end{tabular}

\subsubsection{Control of Erosion Rates}

Control of Erosion Rates was estimated considering the contribution of a given soil cover to reduce soil erosion by comparing it with a worst-case scenario (i.e., the land cover that would generate the highest erosion rate at a given point). Soil erosion rates were estimated using the Universal Soil Loss Equation [25], which consists of a tier 3 approach. The equation estimates average soil loss $(A)$ such as:

$$
A=R \times K \times L S \times C \times P
$$

where, (in SU) :

$A=$ average soil loss in ton $\cdot h a^{-1} \cdot$ year ${ }^{-1}$

$R=$ rainfall erosivity factor $\left(M j . m m \cdot h a^{-1} \cdot h^{-1} \cdot\right.$ year $\left.{ }^{-1}\right)$.

$K=$ Erodibility factor (soil resistance), in t.h. $\mathrm{Mj}^{-1} \cdot \mathrm{mm}^{-1}$

$L S=$ Dimensionless factor given by pixel length and slope

$C=$ Dimensionless factor ranging from 0 to 1 , given by soil cover typology

$P=$ Dimensionless factor ranging from 0 to 1 , given by land management practices (here kept constant as 1)

As no information was available to estimate factor $\mathrm{P}$ accurately, it was kept constant as 1. For our approach, we considered that the Control of Erosion Rates service was given by avoided erosion $\left(A_{a}\right)$ when factor $C_{a}=1$ (soil without any natural cover), which can be re-written as:

$$
A_{a}=R K L S\left(1-C_{a}\right)
$$

Factor $\mathrm{K}$ was obtained by combining information from national soil cartography available at http://sniambportal.apambiente.pt (accessed on 1 September 2021) and national literature. European estimates for Factor C [26] were refined per Portuguese LULC classes based on [27] (see Supplementary Material Table S2). Factor R was based on national statistics publicly available at http:/ / geo.snirh.pt/AtlasAgua / (accessed on 1 September 2021) (required conversion of American to SI units based on [28]. Factors LS (combined) are given by:

$$
L S=\left(\frac{\lambda}{22,13}\right)^{0.4}\left(\frac{\sin \beta}{0,0896}\right)^{1.3}
$$


where:

$\lambda=a * p ; a=$ flow accumulation model (ArcGIS); $p=$ pixel size given by DEM $\beta=$ slope (in degrees) given by DEM

All calculations were performed in ArcGIS using raster calculation operations. We selected the finest resolution possible for the raster cells $(250 \times 250 \mathrm{~m})$, but, by definition, when performing raster calculations our results were not mapped using the LULC polygons from the COS07 cartography as unit of analysis (same as explained for Bird Diversity). However, when depicting spatial relationships (see Section 2.1), we averaged raster cell values per LULC polygon to make results comparable.

\subsubsection{Climate Regulation through Carbon Sequestration}

Carbon Sequestration was estimated as the balance of gains and losses of carbon in both biomass (above and belowground) and soil, considering the land-use transitions that occurred between 1990 and 2007 (and assuming these transitions occurred at a constant rate). IPCC guidelines point to a 20-year transition period to be considered for carbon balances, for the stabilization of carbon fluxes that are slow and/or occurring between two different states [29,30]. Owing to the LULC cartography available (from 1990 and 2007), the analysis was limited to a period of 17 years.

For estimating carbon balances, we first determined carbon gains by calculating mean annual biomass increments as reported in NIR (Tables 8 and 9), converted into tonC $\cdot \mathrm{ha}^{-1} \cdot \mathrm{year}^{-1}$ using the appropriate conversion factors (root-to-shoot, biomass expansion factor, and carbon fraction) (see Supplementary Material Table S3.). Next, we determined carbon losses by using data on timber harvesting, observed land-use transitions (from 1990 to 2007), maps of burned areas, and information on natural mortality to determine:

- Mortality by timber harvesting (spatialization of statistical data allowed determining harvesting rate for the given years at each polygon of interest, i.e., polygons with timber harvesting plantations).

- Mortality by fire (total loss of biomass in polygons that experienced fire events, based on official fire maps for 2007, available at http:/ / www2.icnf.pt/portal/florestas/dfci/ inc/mapa (accessed on 1 September 2021)).

- Mortality by transition (total or partial loss of biomass due to land-use transition, from 1990 to 2007, observed in a given polygon).

- Natural mortality, as determined and reported by the NIR (Table 10).

Table 8. Biomass increments for forest land-uses.

\begin{tabular}{cc}
\hline Forest KP Classes & Mean Annual Increment $\left(\mathbf{m}^{3} / \mathbf{h a}\right)$ \\
\hline 01. Pinus Pinaster & 5.6 \\
\hline 02. Quercus Suber & 0.5 \\
\hline 03. Eucalyptus & 9.5 \\
\hline 04. Quercus Rotundifolia & 0.5 \\
\hline 05. Other Quercus & 2.9 \\
\hline 06. Other Broadleaves & 2.9 \\
\hline 07. Pinus Pinea & 5.6 \\
\hline 08. Other Coniferous & 5 \\
\hline
\end{tabular}


Table 9. Biomass increment estimates for non-forest land-uses.

\begin{tabular}{ccc}
\hline Non-Forest KP Classes & $\begin{array}{c}\text { Aboveground Mean Annual } \\
\text { Increment }\end{array}$ & $\begin{array}{c}\text { Belowground Mean Annual } \\
\text { Increment }\end{array}$ \\
\hline 12. Vineyards & 0.17 & 0.14 \\
\hline 13. Olive & 0.39 & 0.06 \\
\hline 14. Other Permanent & 0.42 & 0.07 \\
\hline 15. Grassland & 0.53 & 0.94 \\
\hline 18. Shrubland & 0.44 & 0.25 \\
\hline
\end{tabular}

Table 10. Natural mortality rates for forest land-uses. Source APA 2014.

\begin{tabular}{cc}
\hline Forest KP Classes & Mortality (\% of Annual Increment) \\
\hline 01. Pinus Pinaster & $0.77 \%$ \\
\hline 02. Quercus Suber & $0.97 \%$ \\
\hline 03. Eucalyptus & $0.83 \%$ \\
\hline 04. Quercus Rotundifolia & $0.8 \%$ \\
\hline 05. Other Quercus & $0.93 \%$ \\
\hline 06. Other Broadleaves & $1.23 \%$ \\
\hline 07. Pinus Pinea & $0.23 \%$ \\
\hline 08. Other Coniferous & $1.1 \%$ \\
\hline
\end{tabular}

All information was converted to tonC $\cdot \mathrm{ha}^{-1} \cdot \mathrm{year}^{-1}$ to allow comparisons. The Carbon sequestration service was given by the positive carbon flows estimated (above 0 tonC $\cdot$ ha $^{-1} \cdot$ year $\left.^{-1}\right)$. Data was managed in a specific geodatabase, and calculations were performed in ArcGIS and Access (Microsoft Office). Emission/sequestration coefficients were thus obtained for each land-use transition, resulting in a carbon emission/sequestration map.

\subsubsection{Provisioning ES}

Fiber Production was estimated as mean annual increments of forests trees as presented in the NIR (reported for KP forest classes, see carbon sequestration above), deducing biomass losses due to natural mortality. Spatialization of ES supply was possible after harmonization of legends between KP classes and COS07 (see Supplementary Material Table S4.)

Mapping of crop production was based on the establishment of a correspondence between the main crops in the study area (as listed in the official statistics) and COS07 classes. We first listed and systematized the main crops, areas (ha) and productivity (ton/ha) in the study area as extracted from the statistics bureau. Once the correspondence with land use classes was made (in certain cases, more than one crop was attributed to the same land-use class; only "pure" land use classes were considered), average productivity was estimated for each land-use class (COS07)-see Supplementary Material Table S5 for established relationships.

Extensive livestock production (or the capacity of ecosystems to support extensive livestock production) was quantified and mapped by determining average livestock densities (for calves, dairy cattle, and sheep) in pasture areas within the study region, using official national statistics at the municipality level. As it was not possible to geographically identify pastures where each unit of livestock production occurs, average livestock density was estimated considering the two main species together (cattle and sheep) for the given pasture area in national statistics for each municipality. Next, average livestock values were spatialized by attributing them to meadow and pasture areas as defined by $\operatorname{COS}^{\prime} 07$. 
Due to the identified disparities between pasture areas reported in $\operatorname{COS}^{\prime} 07$ and pasture areas reported in the national statistics, the resulting values presented in the map should not be aggregated.

\subsection{Spatial Relationships and Interactions}

The analysis of spatial relationships and interactions between ecosystem condition (EC) and the supply of ecosystem services (ES) is intended to explore the outcomes of the MAES initiative envisioning its potential contribution to landscape planning in the region. This analysis was conducted from two different perspectives: the assessment of statistical correlations and the analysis of the spatial distributions and relationships between EC and ES.

The models used for bird diversity and control of erosion rates required mapping using raster/grid cells of finer resolution as the unit of analysis (as detailed in the corresponding section), and here they were analyzed along with the other variables at the polygon level by averaging cell values per LULC polygon of the COS07 cartography.

For the statistical correlations, we first considered five levels for each EC indicator. We took the semi-quantitative 1 to 5 scale already assessed for bird and plant diversity, as well as the ecological value of plant communities. For the soil organic matter indicator, we categorized the values into five levels using Jenks/Natural breaks [31]: very low (0-34 tC/ha), low (34-56), medium (56-69), high (69-82) and very high (82-113). These levels are in accordance with the range of values for soil organic matter previously reported in Alentejo [32]. We then analyzed ES supply for each EC level by applying the KruskalWallis rank test [33] on the EC levels' medians to detect significant differences of ES supply between each level (i.e., to evaluate whether different levels of EC result in different ES supply). We also performed a Jonckheere-Terpstra test [34,35] to identify positive or negative trends in the relationship between the supply of each ES and EC level (i.e., to evaluate whether increasing/decreasing EC levels result in higher/lower ES supply). The statistical work was conducted in RStudio (version 4.0.5).

To show an integrated overview of the distribution of ES supply and EC levels in Alentejo, we normalized all the variables into a 0 to 100 scale to make them comparable. To spatially visualize the relationships between the ES and EC indicators, we overlapped the normalized ES supply and the normalized sum of all EC indicators. We also indicate the relationship per LULC typology, differentiating between agriculture, agroforestry, and forest/shrubland classes. This analysis allowed us to identify how EC condition is related to ES supply in Alentejo.

\section{Results}

The results of the assessment are presented in maps showing the distribution of the indicators for ecosystem condition (EC, Figure 3) and the ecosystem services supply (ES, Figure 4) within Alentejo. The breakdown of results per ecosystem type is summarized in Supplementary Material Table S6. Other graphs and maps show the spatial relationships and interactions between EC and ES (Figures 5-9). 

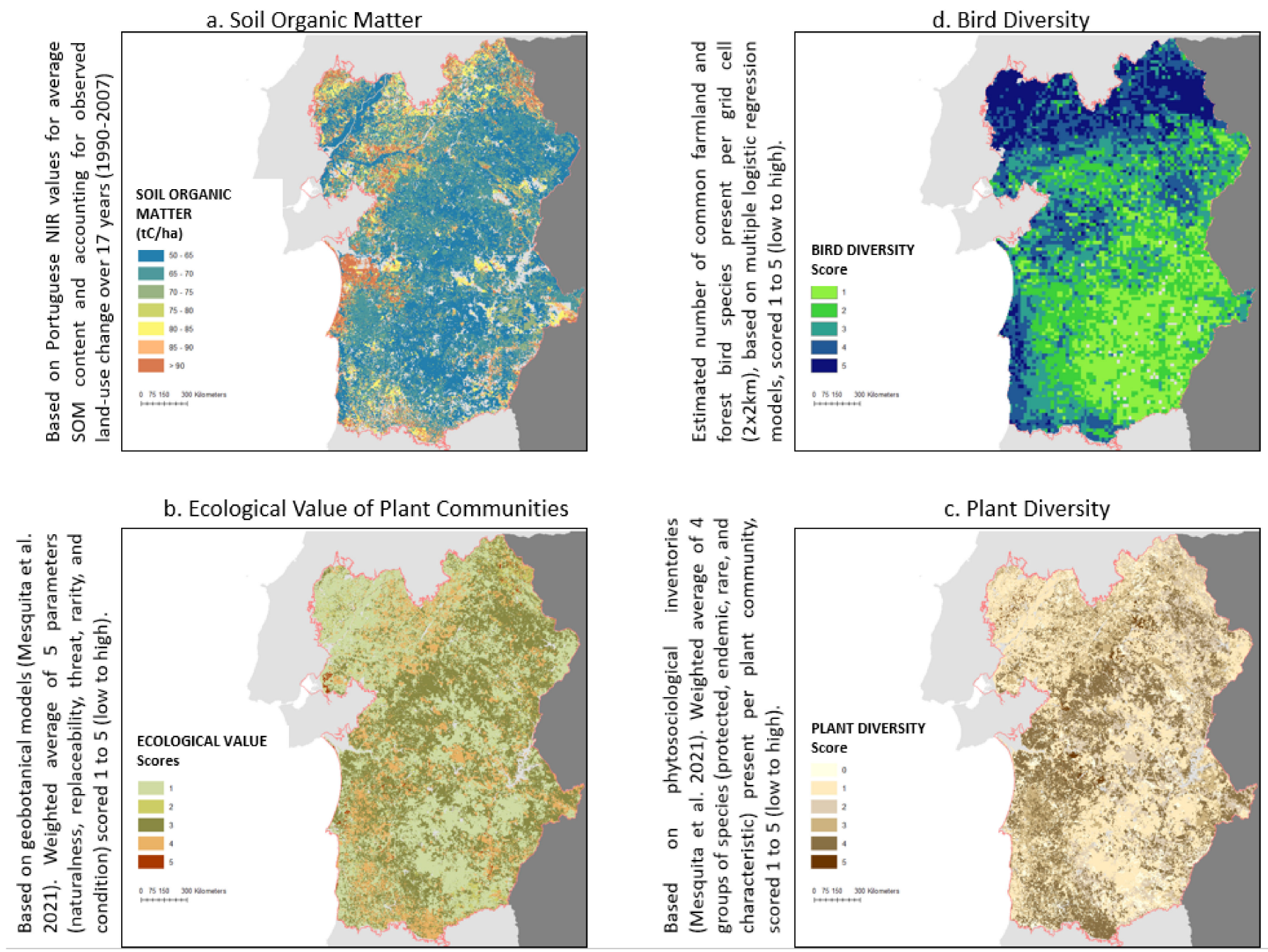

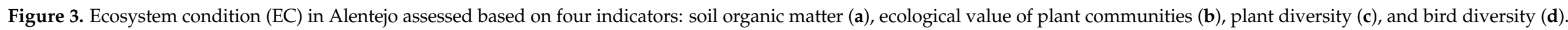


a. Control of Erosion Rates
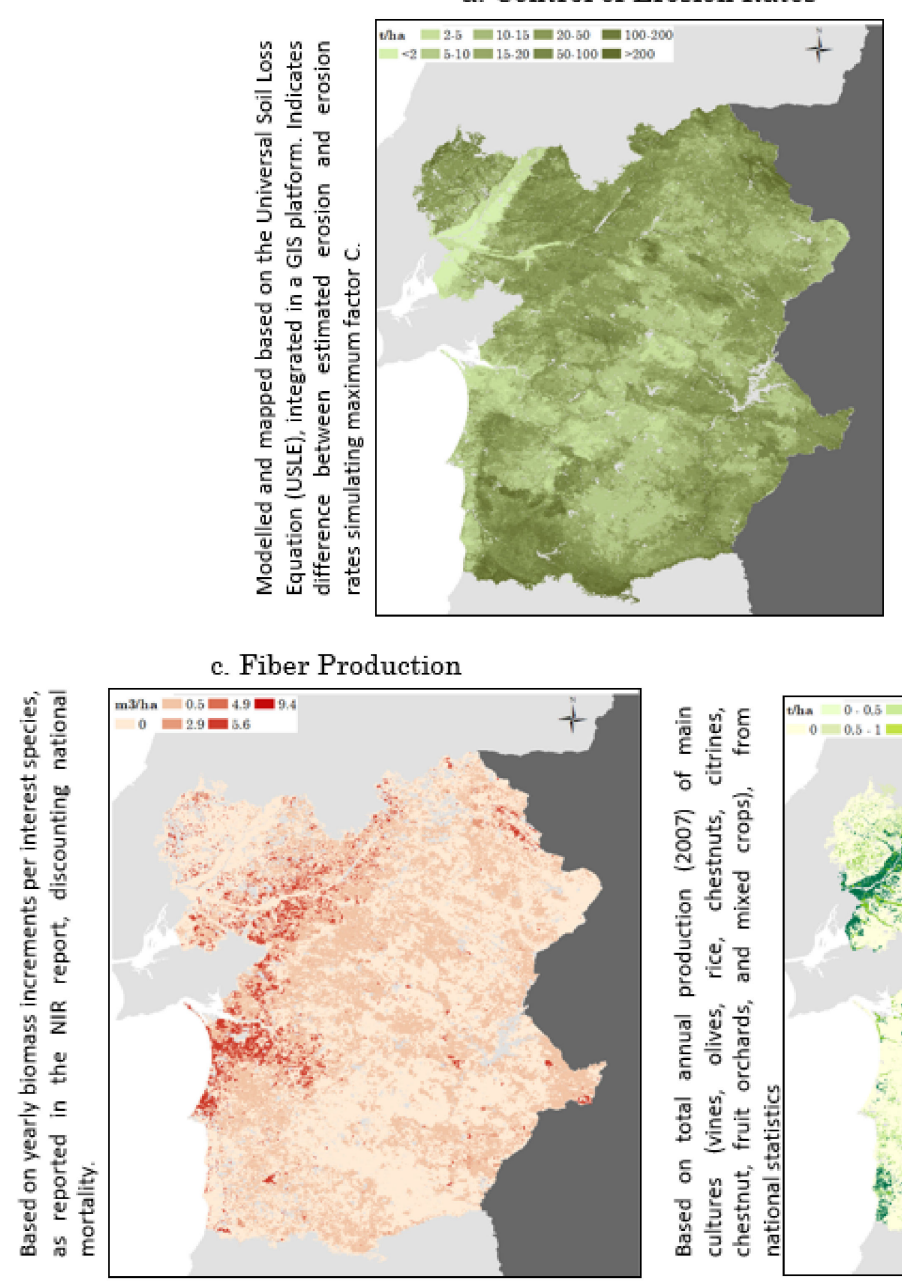

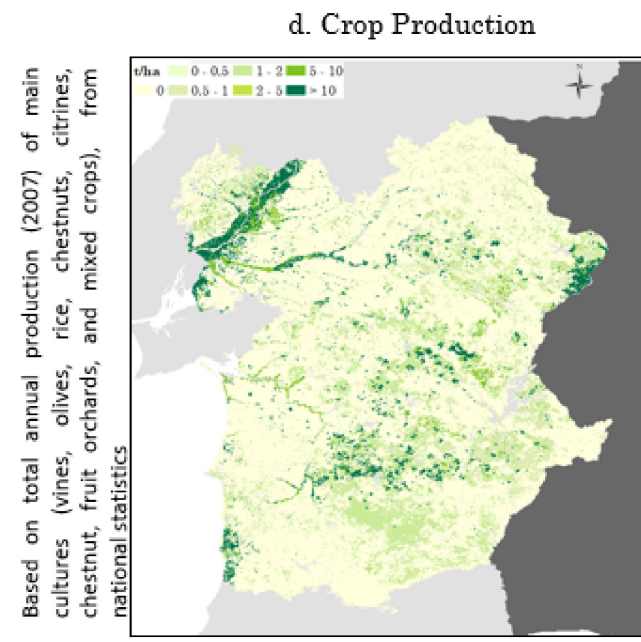

b. Carbon Sequestration

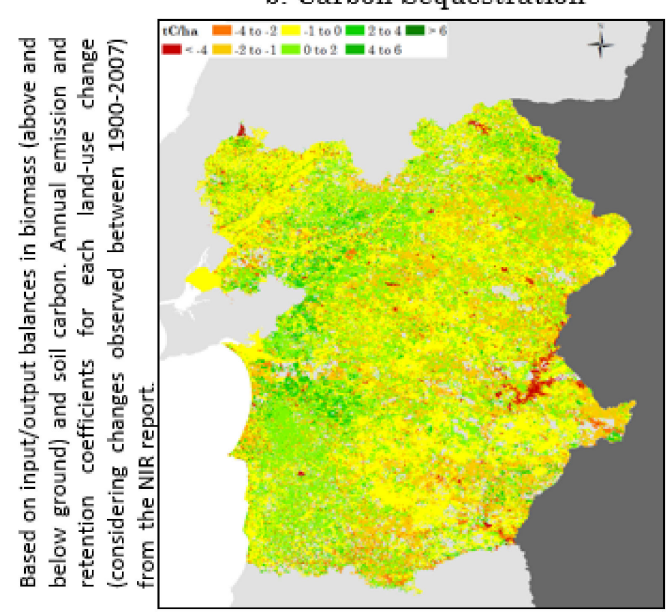

. Livestock Production

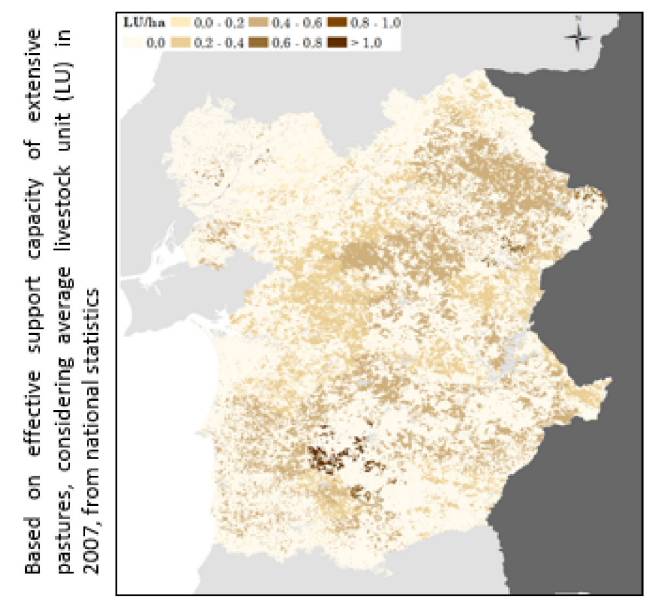

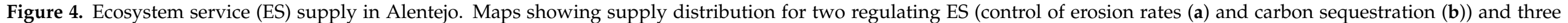
provisioning ES (fiber (c), crop (d), and extensive livestock production (e)). 


\section{ORGANIC MATTER}

(a)

\section{Carbon Sequestration (CS)}

st $p<0.05$, increasing

Kruskal-Wallis test $p<0.05$
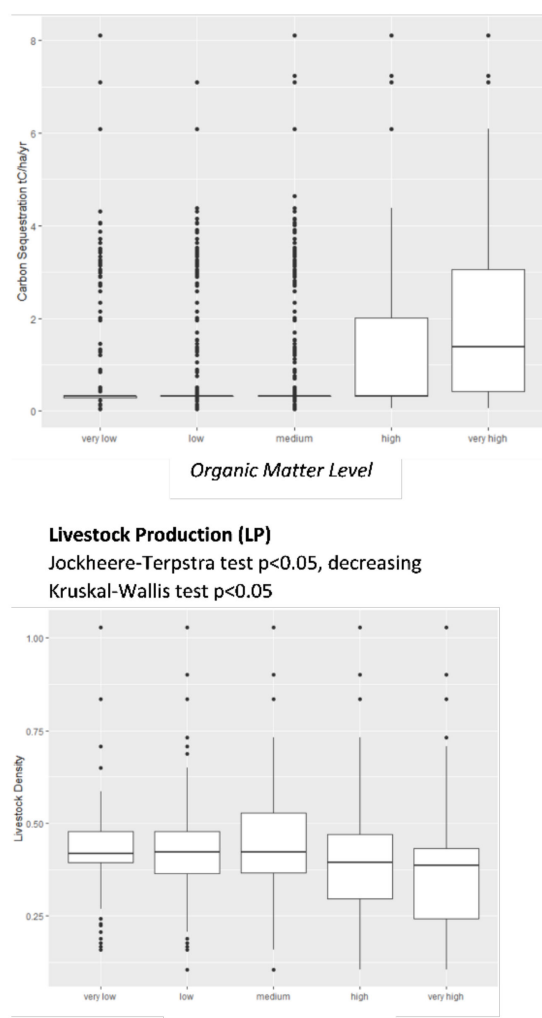

ockheere-Terpstra test p<0.05, increasing

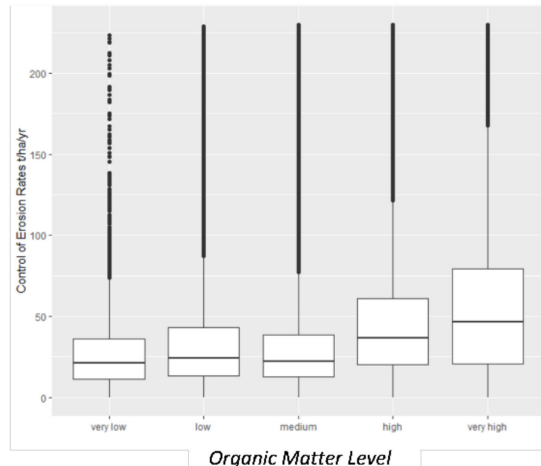

Crop Production (CP)

ockheere-Terpstra test $p<0.05$, decreasin

ruskal-Wallis test $p<0.05$

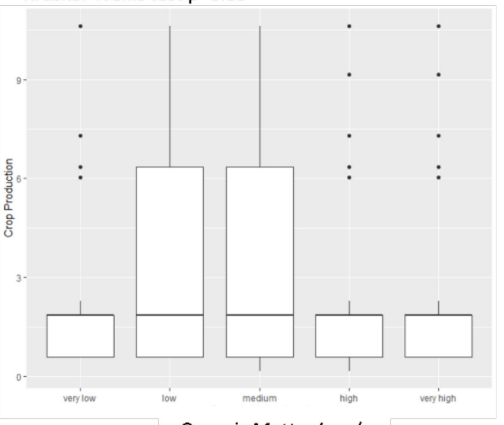

Organic Matter Level

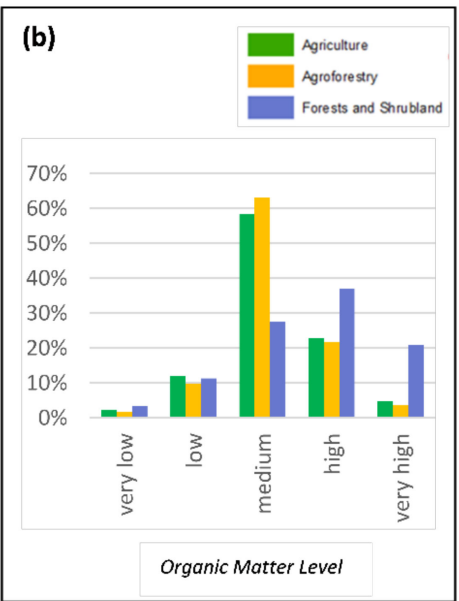

\section{Fiber Production (FP)}

Jockheere-Terpstra test $p<0.05$, increasin

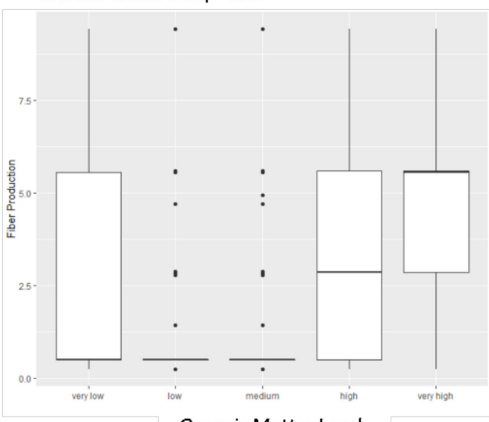

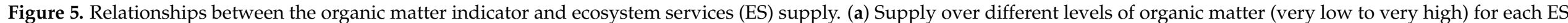
assessed. (b) Representation (\% area) of different land-use typologies (agriculture, agroforestry, and forest/shrubland) per organic matter level. 


\section{ECOLOGICAL VALUE OF PLANT COMMUNITIES}

(a)

Carbon Sequestration $(\mathrm{CS})$
Jockheere-Terpstra test $\mathrm{p}<0.05$, decreasing

Kruskal-Wallis test $p<0.05$

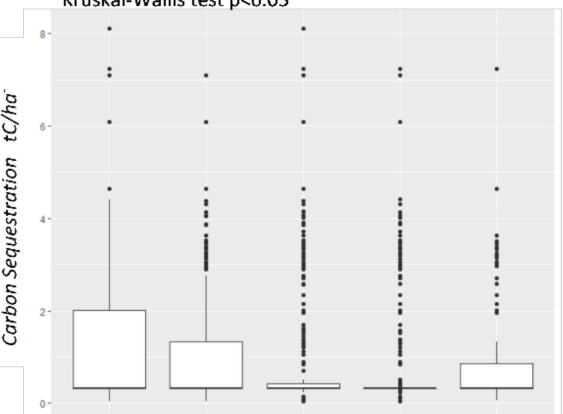

Ecological Value of Plant Communities Level

\section{Livestock Production (LP)}

Jockheere-Terpstra test $p<0.05$, increasing Kruskal-Wallis test $p<0.05$

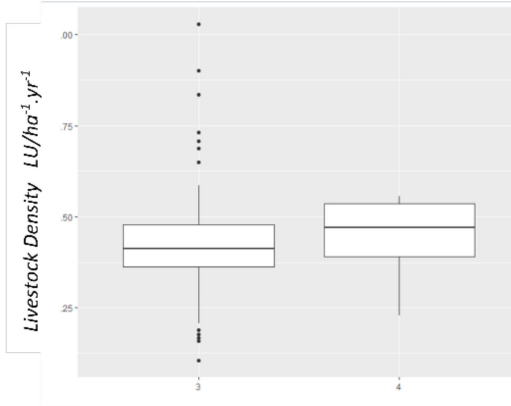

Ecological Value of Plant Communities Leve

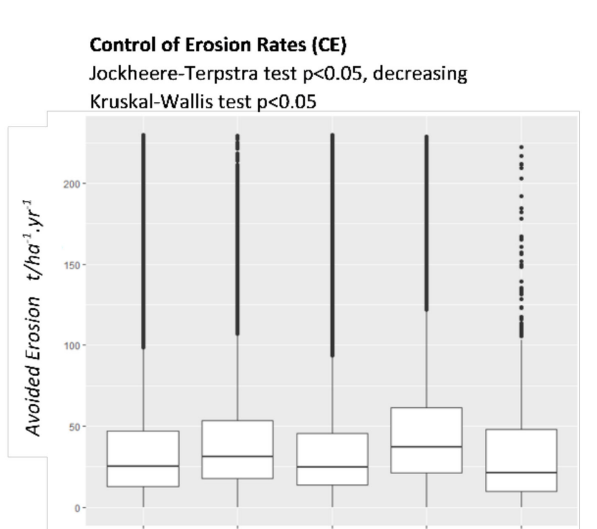

Ecological Value of Plant Communities Leve

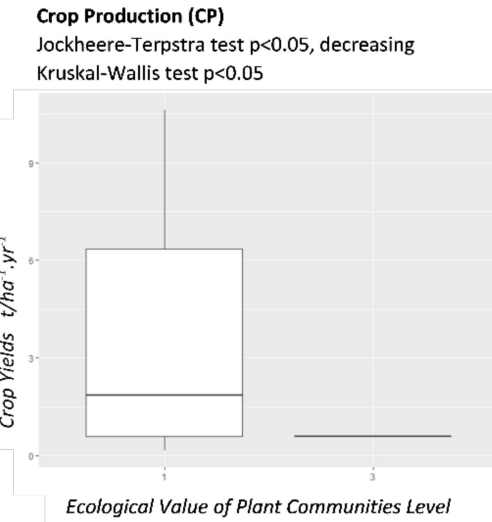

Crop Production (CP)

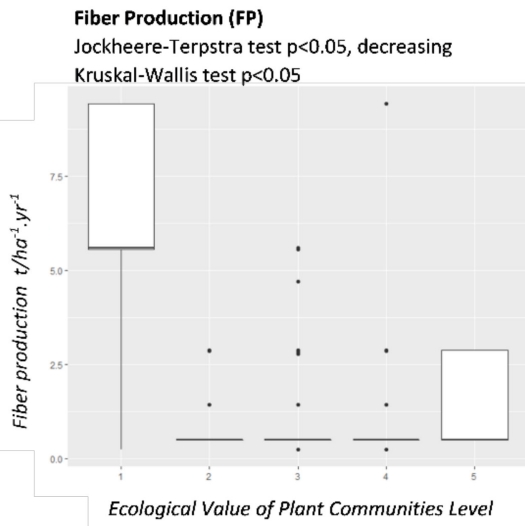

Fiber Production (FP)

Ecological Value of Plant Com

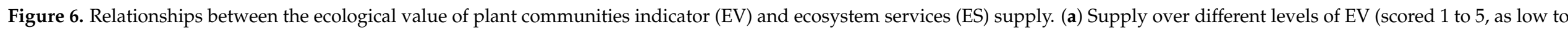
high) for each ES assessed. (b) Representation (\% area) of different land-use typologies (agriculture, agroforestry, and forest/shrubland) per EV level (1-5). 


\section{PLANT DIVERSITY}

(a)

Jockheere-Terpstra test $p<0.05$, decreasing Kruskal-Wallis test $p<0.05$

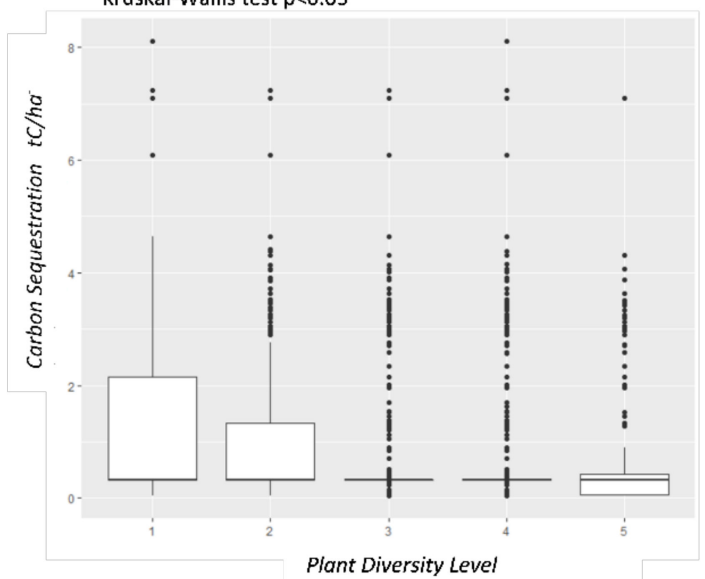

Plant Diversity Level

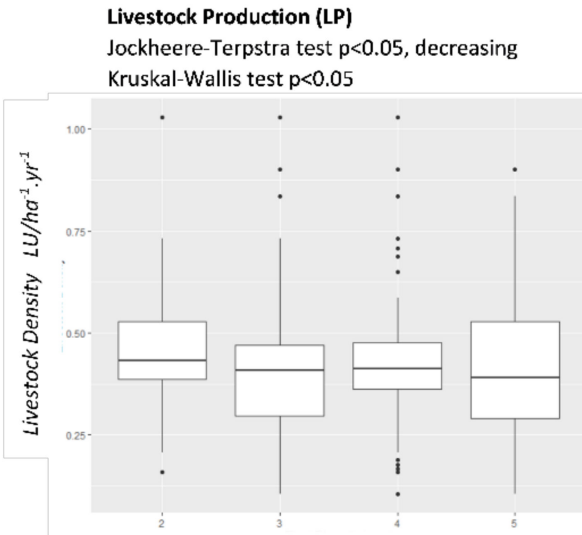

Plant Diversity Leve
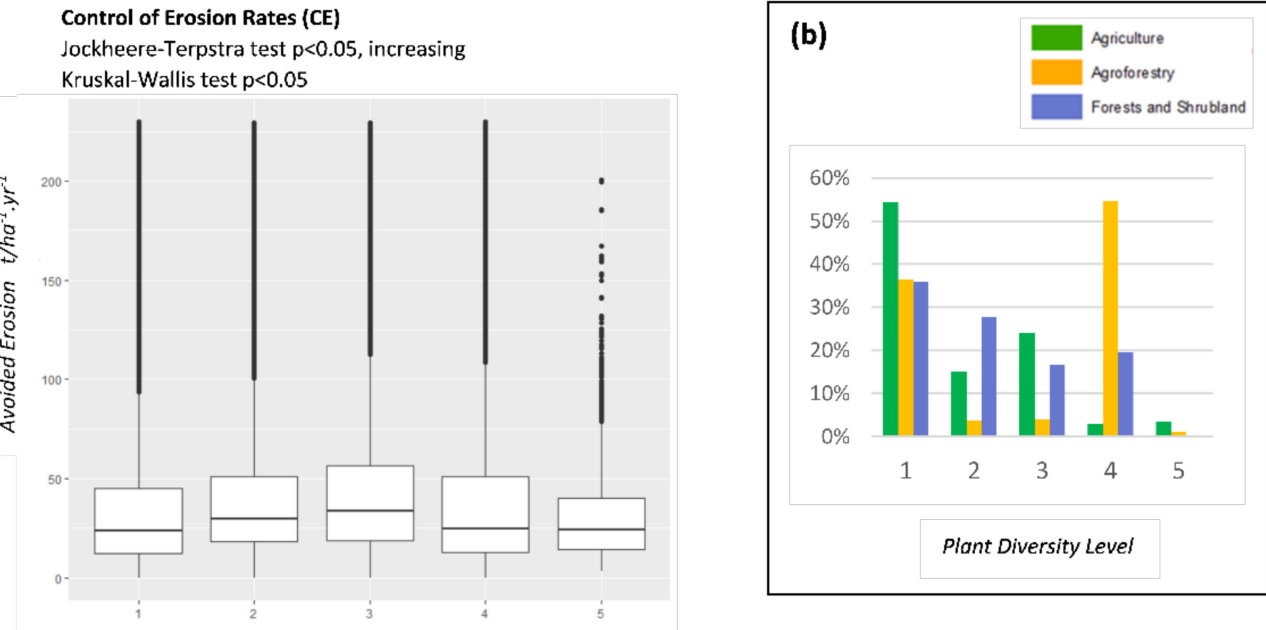

Plant Diversity Level

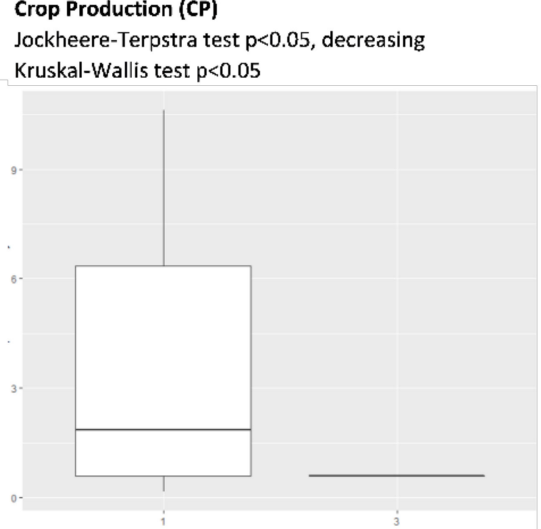

Plant Diversity Level
Fiber Production (FP)

Jockheere-Terpstra test $p<0.05$, decreasing

Kruskal-Wallis test $p<0.05$

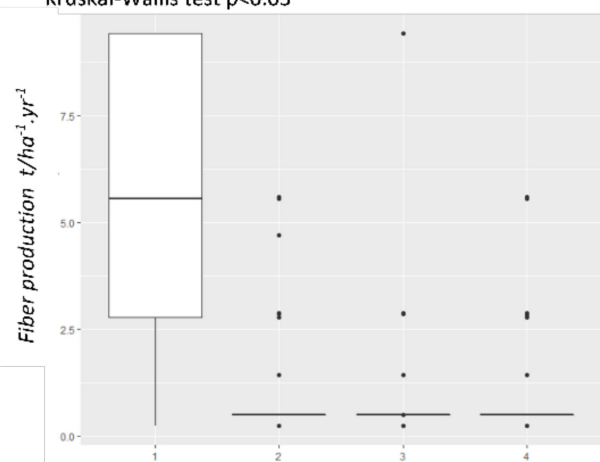

Plant Diversity Level

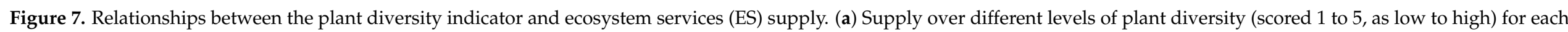
ES assessed. (b) Representation (\% area) of different land-use typologies (agriculture, agroforestry, and forest/shrubland) per plant diversity level (1-5). 


\section{BIRD DIVERSITY}

\section{(a)}

Carbon Sequestration Jockheere-Terpstra test $p<0.05$, increasing Kruskal-Wallis test $p<0.05$

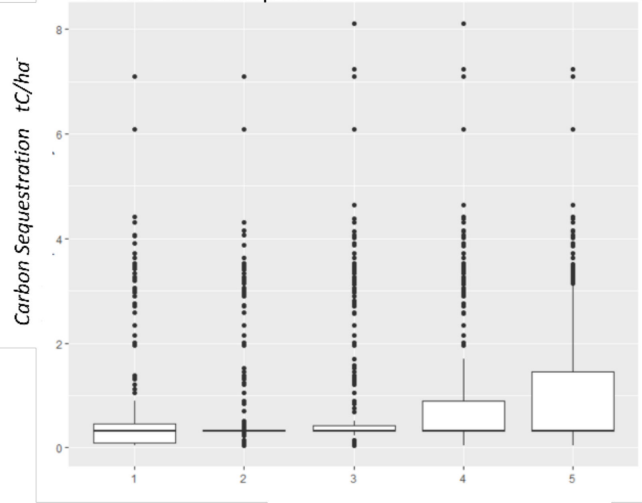

Bird Diversity Level

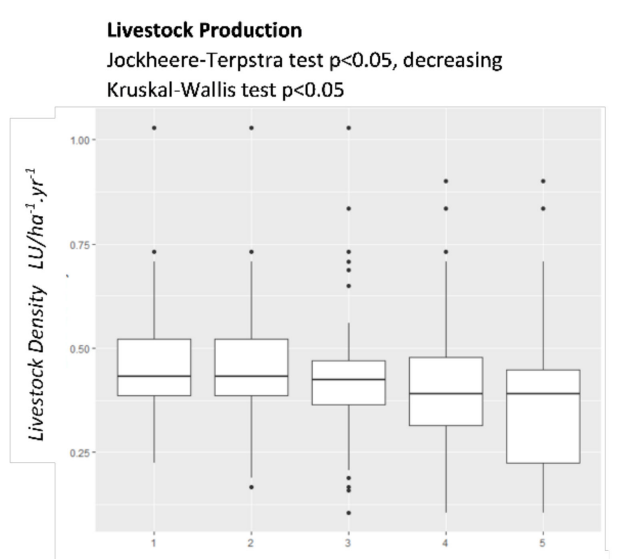

Bird Diversity Level

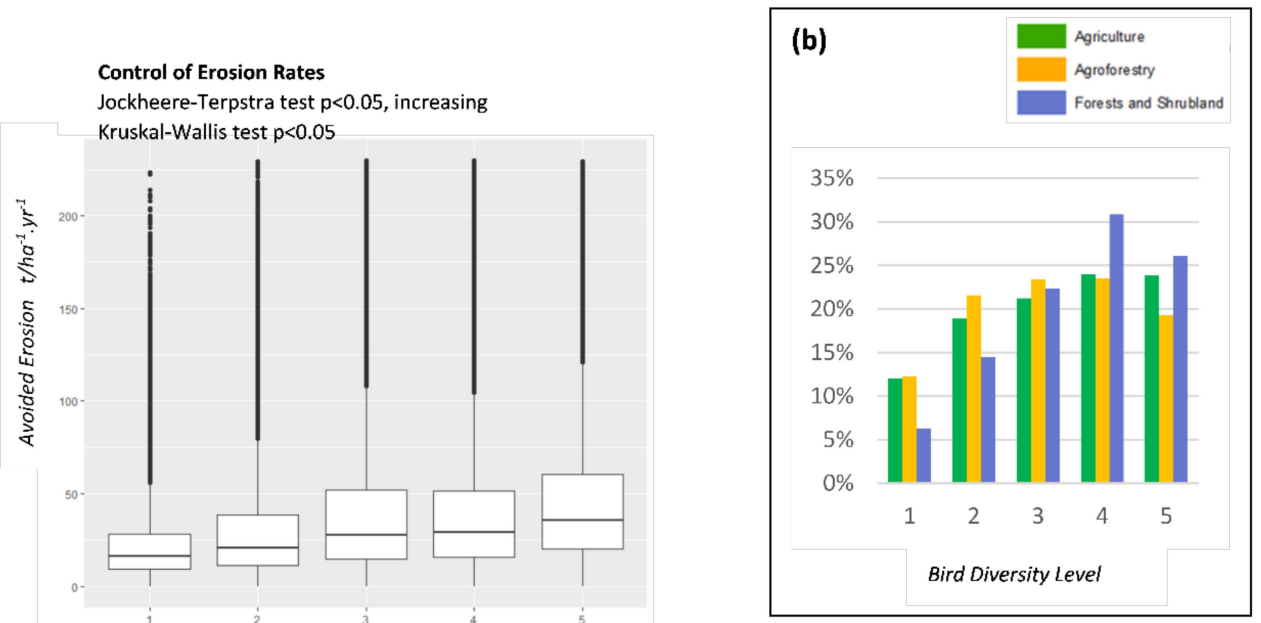

Bird Diversity Level

\section{Crop Production \\ Jockheere-Terpstra test $p<0.05$, increasing}

Kruskal-Wallis test $p<0.05$

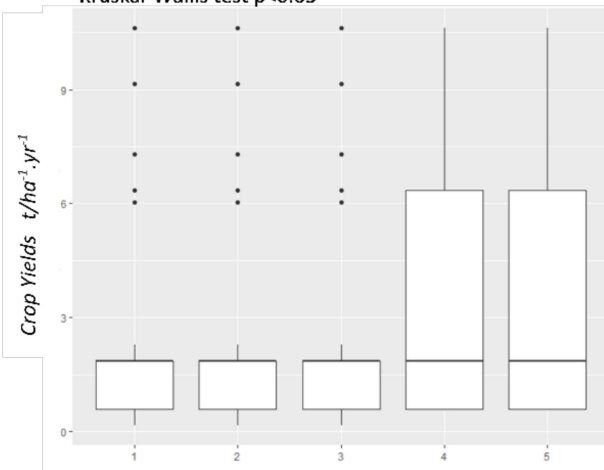

Bird Diversity Level

\section{Fiber Production}

Jockheere-Terpstra test $p<0.05$, increasing

Kruskal-Wallis test $p<0.05$

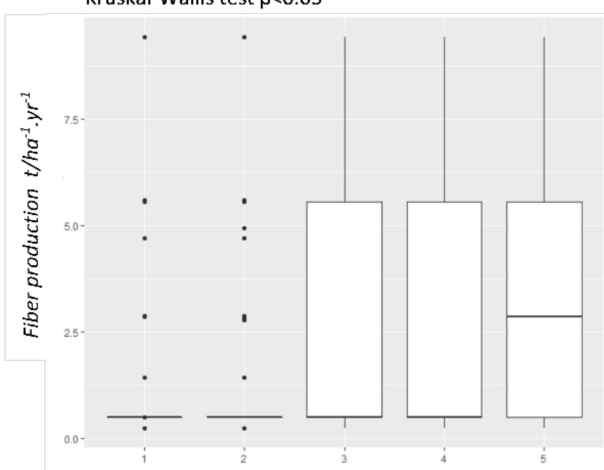

Bird Diversity Leve

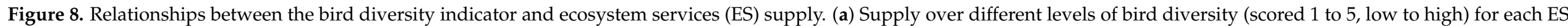
assessed. (b) Representation (\% area) of different land-use typologies (agriculture, agroforestry, and forest/shrubland) per bird diversity level (1-5). 

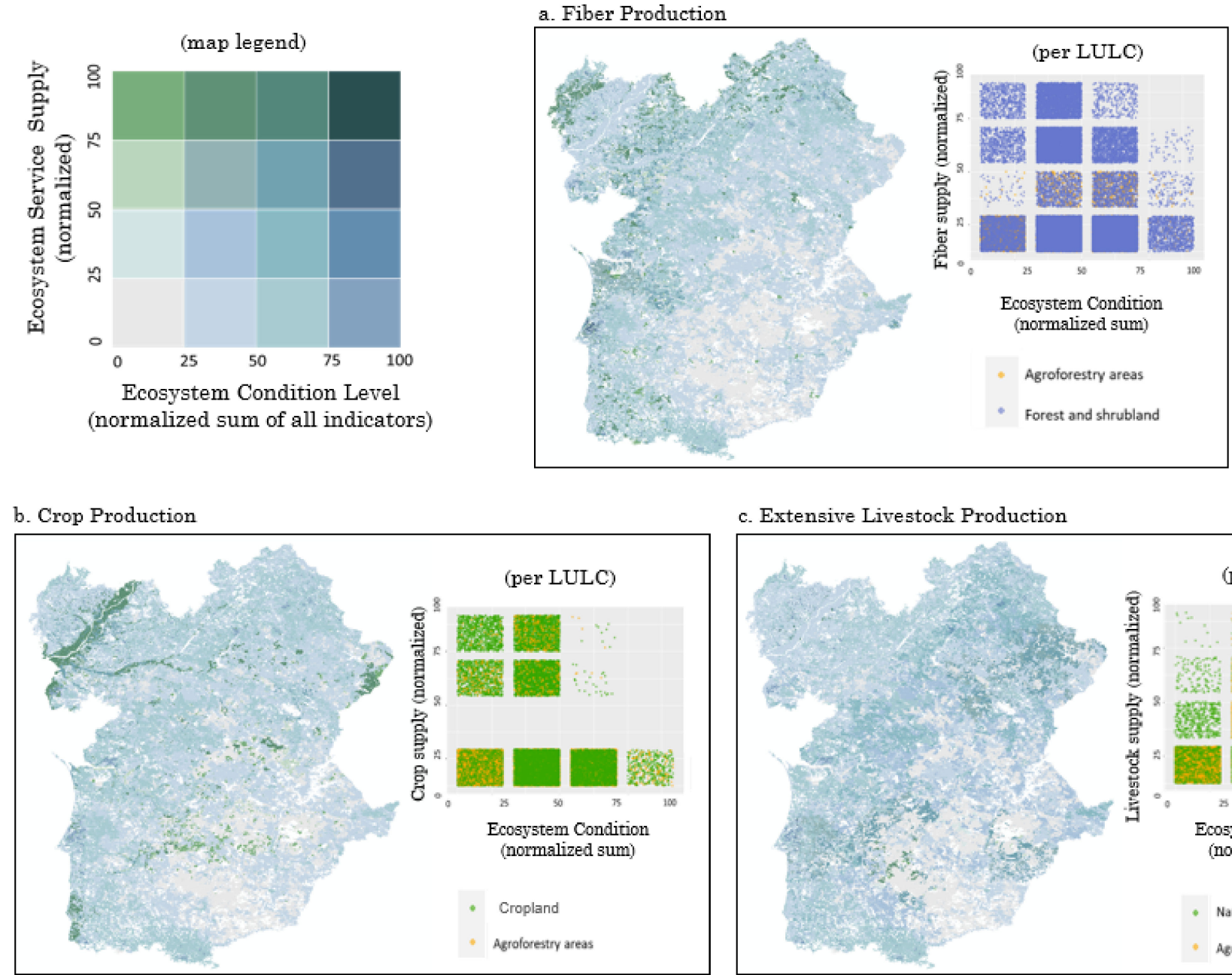

c. Extensive Livestock Production

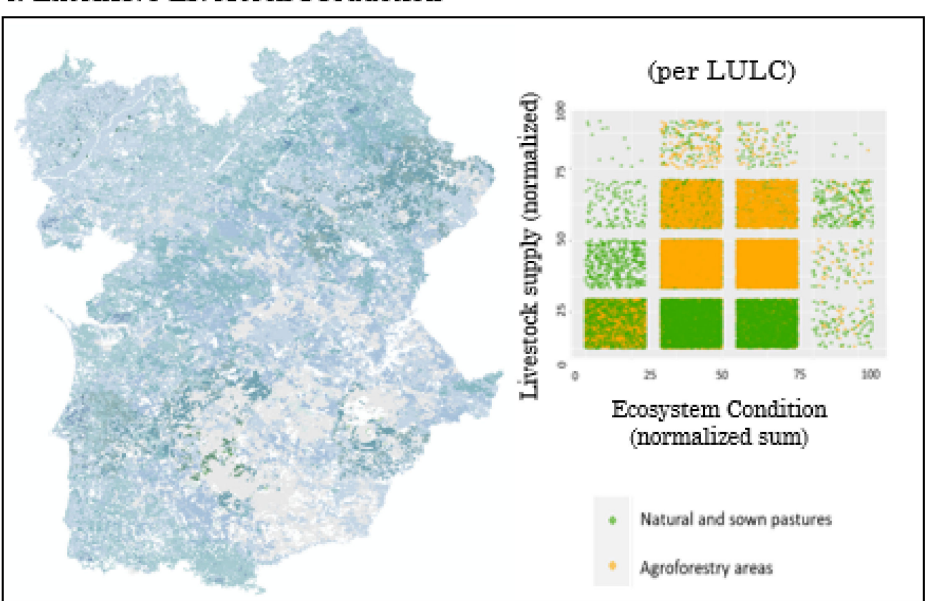

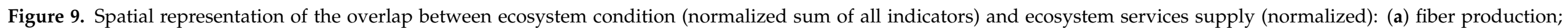

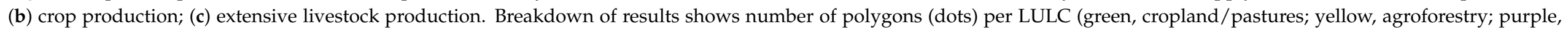
forest/shrubland) 


\subsection{Ecosystem Condition (EC)}

Soil organic matter mapping showed average organic matter content in Alentejo at around $50-75 \mathrm{tC} /$ ha (Figure 3a). Only $12 \%$ of the study area presented OM content above $85 \mathrm{tC} /$ ha. OM concentrations were overall higher in the north and southwest of the region, mainly in forest and shrubland ecosystems. Results for the EC indicator ecological value of plant communities (Figure 3b) shows most of the region presented lower scores (1-2). Areas with the highest score (5) can be sparsely found along the west coast (in dune/paleodune and sea cliff ecosystems with a higher preservation value or presence of successional evolution) and to the northeast and southeast of the region (in Quercus suber dominated agroforestry ecosystems with low agricultural intensity). Higher plant diversity was found in the center and southwest of Alentejo (Figure 3c), mainly in agroforestry and forest ecosystems characterized by sandy soils. As for bird diversity (Figure 3d), over $13 \%$ of the study area presented the highest score (5). Higher bird diversity scores were found mainly in broadleaved deciduous forests, temperate Mediterranean scrubs, and in inland rock cliff ecosystems.

\subsection{Ecosystem Services (ES)}

In terms of control of erosion rates (Figure 4a), higher service supply (over $50 \mathrm{t} /$ ha/year) was found along mountainous regions to the southwest and northeast of the region. Grasslands and forests (Quercus suber forests) are the most erosion controlling ecosystems. Carbon sequestration was determined using carbon balances, and results show positive rates (sequestration) mainly present throughout the region but predominantly in the southwest (Figure 4b). Negative rates (carbon emission) dominate the eastern part of Alentejo. Higher service supply (i.e., carbon sequestration rates) are associated with transitions to forest ecosystems, namely areas converted to broadleaf forests and Pinus pinea, while the highest emissions rates were found in areas that were converted from forest to non-forest uses over the 17 years analyzed (1990-2007).

Three provisioning ES were assessed based on the mean annual increment of forest species of interest (fiber production) and spatialization of statistic data reports (crop and extensive livestock production). Spatialization of data was limited to specific land-use typologies (e.g., fiber production is not accounted for in grasslands or croplands), which explains the larger areas where ES supply is absent (" 0 ") in these maps (Figure 4c-e, respectively). Fiber production in Alentejo is mostly present at lower rates in large extents of agroforestry ecosystems and Quercus suber and Quercus rotundifolia forests, mainly in central Alentejo (Figure 4c). Nevertheless, other ecosystems dominated by fast-growing species (Eucalyptus sp. and Pinus pinaster) can be found in the eastern part of the region, where much higher rates of service supply were found (up to $9.4 \mathrm{~m}^{3} / \mathrm{ha}$ ). As for crop production, a higher service supply can be found along the Tagus Valley (northwest) and sparsely throughout the region where cropland is present. Finally, results for livestock production shows the level of service supply ranging from 0.2 to over $1 \mathrm{LU} /$ ha. Levels higher than the 0.6-0.8 ha category are found mainly in grassland ecosystems, whereas lower levels are present in agroforestry ecosystems (extensive grazing).

\subsection{Spatial Relationships and Interactions}

Figures 5-8 show the relationship between each ecosystem condition (EC) indicator and the supply of the different ecosystem services (ES) assessed. The candlestick charts in Figures 5-8 indicate how ES supply changes with increasing levels of EC-each figure refers to one EC indicator. Kruskal- Wallis tests for all variables indicate significant differences $(p>0.05)$ in ES supply for the different levels of EC. Based on the Jonckheere-Terpstra tests, results indicate a positive relationship $(p>0.05)$ between the supply of regulating ES (control of erosion rates and carbon sequestration) and higher levels of bird diversity and soil organic matter (Figures 5 and 8, respectively). Contrastingly, the supply of CE and CS seems to decrease with increasing plant diversity and ecological value of plant communities (Figures 6 and 7, respectively). 
As for provisioning ES, supply levels mainly decrease with increasing levels of EC indicators, except for fiber production (which increases with increasing organic matter, Figure 5) and extensive livestock production (which increases with increasing ecological value of plant communities, Figure 6). These results were expected since (1) higher levels of organic matter were found in production forests and (2) the higher supply of extensive livestock refers mainly to medium range values (around $0.5 \mathrm{LU} / \mathrm{ha}$ ), which occur in agroforestry systems that scored medium-high in the ecological value EC indicator.

Additionally, we identified overlaps between ES supply and EC indicators. Figure 9a-c show the distribution of normalized ES supply for fiber, crop, and livestock production, respectively, in relation to the normalized sum of all EC indicators (ecological value of plant communities, plant and bird diversity, and soil organic matter). Overlap results for the two regulating ES (control of erosion rates and carbon sequestration) are shown in Supplementary Material Table S7. We also present the breakdown of the overlap between ES and EC per land-use/land cover (LULC), indicating which LULC class is more predominant under different combinations of ES supply and EC level. For instance, in Figure 9c, we see that intermediate levels of EC condition and ES supply are more predominant in agroforestry areas (yellow dots) than in pastures/grasslands (green dots). Areas of high ES supply and below-average EC level (green shades on the top left of the legend) can be found throughout Alentejo for the three provisioning ES, particularly to the north and northeast of the region (Figure 9a,b) but also sparsely in the central part of Alentejo (Figure 9b,c). This indicates a high supply of ES in areas of poor ecological condition.

\section{Discussion}

Our discussion is framed by the objectives earlier stated: first by considering the proposed analytical framework and outcomes of the ptMAES study in the context of future MAES initiatives, and second by discussing the assessed relationships between ecosystem services (ES) and ecosystems' condition (EC).

\subsection{Proposed Analytical Framework}

We identify several advantages and challenges of the proposed analytical framework for implementing national policies targeting the EU Biodiversity Strategy to 2020 and 2030, as well as assisting the launch of MAES initiatives in Portugal.

The methods proposed for assessing the ES control of erosion rates bring novelty to the soil arena, being a first attempt to detail a C-factor for the national land-use cartography classes (COS07) and a GIS-based application of the USLE at a regional scale in a context of ES assessment. This resulted in a highly detailed map (Figure 4a), capturing spatial variability with the potential to assist landscape planning at multiple scales. Our estimates proved to be more detailed and reliable than soil erosion maps produced at the European scale (JRC PESERA) based on remote sensing/LULC data, although our range of estimates falls within the reported values for Portugal. However, the proposed approach fails to incorporate the temporal variability of ES supply and the impacts of different land management options, which can impact observed erosion rates [23].

The approach for mapping and assessing the ES carbon sequestration (Figure $4 \mathrm{~b}$ ) presented several advantages: it uses information already produced for national reporting (UN Framework Convention on Climate Change and Kyoto Protocol), innovatively applied on a spatial-based approach, and it accounts for LULC changes (i.e., temporal and spatial dimension), allowing the ES to be genuinely quantified as flows [36]. Accounting for LULC change is critical as its potential impact on ES supply at different scales has already been called out in the literature [37-39], and LULC changes in Alentejo are significant and mainly driven by agricultural policies [40].

Though the use of regional process-based models could significantly improve outcomes [41], they provide additional challenges in terms of data requirements that might not be readily available for the scale of interest. 
Lack of disaggregated data (i.e., at the farm or local scale) publicly available was also a significant limitation observed in the assessment of provisioning services (Figure 4c-e). Other authors have reported this to be a common limitation of tier-1 approaches for ES mapping [42,43], which is usually the case when mapping provisioning services. In the case of fiber production, this limitation may be solved by using more spatialized annual increment coefficients [44]. This refinement can also be possible based on literature and/or expert opinion while keeping the cost-efficient nature of the proposed framework [45]. Better results can be achieved by integrating Land Parcel Identification System information, which allows for a more detailed spatialization of crop and livestock production [46]. However, using this information in research agendas requires disclosure of personal data and raises confidentiality and data protection issues.

Concerning EC indicators, the advantages of the proposed approach to mapping soil organic matter (Figure 3a) are the same as reported for carbon sequestration, in the sense that it relies on information that is available and collected for national reporting on GHG emissions (UNFCC and Kyoto Protocol), but innovatively spatialized based on LULC cartography while accounting for LULC change. The estimates efficiently account for spatial variability and have the potential to assist landscape planning at multiple scales while falling within the range of values previously assessed based on regional models using sampling data [32]. We also highlight the potential of the proposed biodiversity indicators, namely plant diversity and ecological value of plant communities (Figures 3b,c, respectively), in assisting decision making regarding landscape planning (e.g., protected areas management), as they focus on ecological and functional measures complemented with expert judgment rather than on the presence or absence of species alone. We argue that such integrated solutions conveying expert knowledge to mapping could better improve the assessment of biodiversity-related indicators with increased potential to assist decisionmaking at multiple scales [47,48]. As for the bird diversity indicator (Figure 3d), although the method proposed is suitable for upscaling, rare species with conservation interest were not included in the analysis due to their low observation frequency in the study area. This limitation should be addressed in future applications if the purpose of the assessment is to support nature conservation policies targeting protected species [49]. Moreover, it has been argued that high biodiversity levels in managed landscapes are more likely to be maintained for reasons of intrinsic value (e.g., traditional land management practices), cultural values (e.g., "bequest" ES) or use values ("direct use") than for its functional values or its role in maintaining good ecosystem condition [50]. Our findings in this paper support that it is meaningful to include biodiversity assessments both as ES supply (biodiversity with conservation interest) as well as EC indicators (functional biodiversity) in MAES initiatives aimed at the integration of ES into planning/policy design in humandominated landscapes. Finally, when assessing EC, we argue that priority should be given to indicators that could be related to the ES flow measurement (e.g., soil organic matter for crop production, infiltration rate for water availability, etc.), such as demonstrated by recent findings [51,52].

Overall, the proposed framework can be easily applied at different scales subject to specific refinements dictated by territory spatial variability. This is clearly a major advantage of performing a multi-tiered spatial assessment based on LULC cartography as proposed in the ptMAES study, which has been also pointed out by others [45], However, we acknowledge that in the absence of data limitations (in terms of scale, availability, and coverage), a more comprehensive assessment would be possible, including a larger number of ES and a wider array of EC indicators. Cultural ES, in particular, should not be overlooked as they play an important role in motivating public support and assisting decision-making [53,54]. To make the best out of the available information, certain ES and EC indicators were based on tier-1 approaches (i.e., spatialization of statistical information) (Figure 2), which limited the portrayal of spatial variability and consequent explanatory power of the assessment to better assist decision-making [52]. These issues have been discussed by [55], and our analysis supports the review and directions proposed by the au- 
thors. We highlight that the ptMAES also produced a thematic EUNIS habitat cartography based on interpreting LULC units as territorial units of ecological succession. This was an innovative approach in Portugal, and the outcomes are presented in [22]. Results of EC and ES supply per EUNIS habitat are presented in Supplementary Material Table S6.

\subsection{Spatial Relationships and Interactions}

In this paper, we analyzed the spatial relationships and interactions between EC and ES supply in Alentejo. Our goal was to explore the outcomes of the analytical framework proposed and discuss how they could potentially support landscape planning.

Our analysis indicates overall changes in ES supply rate for varying levels of EC (Figures 5-8). Generally speaking, we expected regulating ES supply to increase with increasing EC (as ecosystems under better ecological conditions potentially sequester more carbon and provide more soil protection) and provisioning ES to decrease with increasing EC (as higher production rates are usually found in monocultural crops or intensive pastures under poorer ecological condition) [56]. Despite this, we found that carbon sequestration rates decrease with increasing levels of plant-related EC indicators (Figures 6 and 7). Two underlying factors explain this result: (1) the great representation of agroforestry systems in good EC (scoring 3 and higher, see Figures $5 b$ and $6 b$ ); and (2) the lower carbon sequestration rates attributed to $Q$. suber /Q. rotundifolia agroforestry systems, which are given by the lower mean annual increment considered for these species in the estimated biomass balance, when compared to other forest species. This means that carbon sequestration is potentially underestimated in these ecosystems and is not true a reflection of their ecological condition [43]. In addition, we found crop and fiber production to increase with increasing EC levels (particularly bird diversity, Figure 8a). We believe this is caused by: (1) the consideration of common farmland and arable land bird species in the distribution models, which estimate high bird presence in cropland and harvested forests alike; and (2) fiber and crop production levels are not real estimates collected in situ but rather result from the specialization of statistical data. This result should be interpreted with caution since bird presence is actually expected to decrease in intensive monocultures [57].

Despite the considerations presented above, when looking at spatial overlaps between the supply of provisioning ES and the normalized sum of all EC indicators (Figure 9), we identify high ES supply rates in areas under below-average EC (green shades in the maps). Since good ecological conditions ultimately underpin the capacity of an ecosystem to supply ES [58,59], these results red-flag areas where the sustainability of ecosystems (and its capacity to supply ES) is threatened in the long term. The breakdown of these results per LULC typology shows that agroforestry land-uses promote higher levels of ES supply (namely crop and extensive livestock production) under best (above-average) ecological conditions (see, for instance, the representation of agroforestry in Figure 9b,c, respectively). This is less evident for fiber production as higher production levels are limited to fast-growing species (Eucalyptus sp. and Pinus pinaster), overshadowing fiber production in Q. suber-/Q. rotundifoliadominated agroforestry systems. However, the bundle of ES supplied by the agroforestry systems present in Alentejo has been widely documented in the literature [60-63].

Our outcomes show examples of how MAES could potentially assist landscape planning. For instance, our results point to planning interventions that could: (i) target and help improve management practices in croplands, timber forests, and grasslands where ES supply is high, but EC is not optimal, and (ii) target agroforestry areas in good EC and which have the potential to supply many ES in the central part of Alentejo. Notwithstanding, we point out that our achievements are specific to this case study and should not be readily transposed to other research or policy contexts.

\section{Conclusions}

In this paper, we present an analytical framework based on LULC cartography to assess ecosystem condition (EC) and ecosystem services (ES) as tested in the ptMAES study. Innovative, multi-tiered information-processing approaches were used, which proved to be 
effective and suitable for upscaling. Our findings leverage new approaches to the potential integration of ES into landscape planning at the regional and national scales. We highlight the usefulness of integrated approaches (e.g., conveying expert knowledge to spatial assessments), as it can better depict spatial variability in the absence of data available at the desirable scale. However, we identify relevant caveats in the proposed analytical framework that should be addressed in the future for a more comprehensive MAES assessment: (1) data availability (in terms of aggregation, scale, and coverage) limited the inclusion of process-based modeling; (2) refinement of results could be achieved with the use of information collected by the public administration if data protection issues are overcome; (3) a wider range of EC indicators and ES should be considered (particularly cultural services); and (5) the selection of EC indicators should better reflect their relationship to ES.

Supplementary Materials: The following are available online at https:/ / www.mdpi.com/article/10 .3390/land10101040/s1: Table S1: LULC CLASSES-AGREGATION CRITERIA; Table S2: FACTOR C (USLE)_ADAPTATION FROM PIMENTA 1999; Table S3: CONVERSION FACTOR FOR BIOMASS TO CARBON; Table S4: HARMONIZATION OF KYOTO PROTOCOL LAND-USE CLASSES WITH COS; Table S5: "PURE“CROPS AND LULC; Table S6: RESULTS PER ECOSYSTEM TYPE/EUNIS HABITAT; Table S7: SPATIAL OVERLAP REGULATING ES; Table S8: BIRD DIVERSITY MODELS.

Author Contributions: L.L.: conceptualization, methodology, formal analysis, investigation, writingoriginal draft, writing — review and editing; T.D.: conceptualization, methodology, writing—review and editing, supervision; C.M.-P.: conceptualization, methodology, writing-review and editing, supervision. All authors have read and agreed to the published version of the manuscript.

Funding: This work has been conducted under the financial support of the National Authority for Biodiversity and Forest Conservation (ICNF) under contract AD 288/2014/ICNF/SEDE and of the Portuguese Foundation for Science and Technology (FCT) through FCT/MCTES (PIDDAC) project UIDB/EEA/50009/2020. The work of L.L. was supported by FCT through the PhD grant SFRH/BD/94195/2013.

Institutional Review Board Statement: Not applicable.

Informed Consent Statement: Not applicable.

Data Availability Statement: Publicly available datasets were analyzed in this study. This data can be found here: https://www.ine.pt/xportal/xmain?xpgid=ine_main\&xpid=INE; https:/ / apambiente. pt/sites/default/files/_Clima/Inventarios/NIR20210415.pdf; https:/ / ebird.org/portugal/home; http:/ / www2.icnf.pt/portal/florestas/dfci/inc/mapa (accessed on 15 September 2021).

Acknowledgments: The authors would like to thank the extended ptMAES working team who greatly contributed to the production of the original data used in this study: Sandra Mesquita, Jorge Capelo, Ivo Gama, Miguel Alves, Vânia Proença, Paulo Canaveira and especially Marco Reis, who, although no longer with us, continues to inspire by his example and dedication to the people he worked with over the course of his fruitful career.

Conflicts of Interest: The authors declare that they have no conflict of interest.

\section{Notes}

1 The 2020 EU Biodiversity Strategy (COM 2011) was built around six mutually supportive and inter-dependent targets that addressed the main drivers of biodiversity loss. They aimed to reduce key pressures on nature and ecosystem services in the EU by setting up efforts to fully implement existing EU nature legislation, anchoring biodiversity objectives into key sectoral policies, and closing important policy gaps. Each target was accompanied by a set of focused, time-bound actions to ensure these ambitions are fully realized.

2 The goal of Target 2 of the EU Biodiversity Strategy 2020 is to "maintain and restore ecosystems and their services", with Action 5 set out to "improve knowledge of ecosystems and their services in the EU".

3 NUTS II refers to the second level of the Nomenclature of Territorial Units for Statistics (NUTS) that is used in Portugal. 


\section{References}

1. Millenium Ecosystem Assesment. Ecosystems and Human Well-Being: Synthesis. Millennium Ecosystem Assessment; Island Press: Washington, DC, USA, 2005.

2. Haines-Young, R.; Potschin, M. Common International Classification of Ecosystem Services (CICES), Version 4.3; Report to the European Environment Agency EEA/BSS/07/007; European Environment Agency: Copenhagen, Denmark, 2013; p. 34.

3. Schröter, M.; Barton, D.N.; Remme, R.P.; Hein, L. Accounting for Capacity and Flow of Ecosystem Services: A Conceptual Model and a Case Study for Telemark, Norway. Ecol. Indic. 2014, 36, 539-551. [CrossRef]

4. Mace, G.M. Whose Conservation? Science 2014, 345, 1558-1560. [CrossRef]

5. Alexander, S.; Aronson, J.; Whaley, O.; Lamb, D. The Relationship between Ecological Restoration and the Ecosystem Services Concept. Ecol. Soc. 2016, 21, 34. [CrossRef]

6. Potschin-Young, M.; Haines-Young, R.; Görg, C.; Heink, U.; Jax, K.; Schleyer, C. Understanding the Role of Conceptual Frameworks: Reading the Ecosystem Service Cascade. Ecosyst. Serv. 2018, 29, 428-440. [CrossRef]

7. Dale, V.H. Ecological Modeling for Resource Management; Springer Science \& Business Media: Berlin/Heidelberg, Germany, 2006; ISBN 978-0-387-21563-1.

8. Maes, J.; Teller, A.; Erhard, M.; Murphy, P.; Paracchini, M.L.; Barredo, J.I.; Grizzetti, B.; Cardoso, A.; Somma, F.; Petersen, J.E.; et al. Mapping and Assessment of Ecosystems and Their Services: Indicators for Ecosystem Assessments under Action 5 of the EU Biodiversity Strategy to 2020; Technical Report (2014-080); Publications Office of the European Union: Luxembourg, 2014; ISBN 978-92-79-36161-6.

9. Burkhard, B.; Kroll, F.; Nedkov, S.; Müller, F. Mapping Ecosystem Service Supply, Demand and Budgets. Ecol. Indic. 2012, 21, 17-29. [CrossRef]

10. European Commission. The EU Biodiversity Strategy to 2020; Official Publication of the European Union: Luxembourg, 2011; ISBN 978-92-79-20762-4.

11. Gonzalez-Redin, J.; Luque, S.; Poggio, L.; Smith, R.; Gimona, A. Spatial Bayesian Belief Networks as a Planning Decision Tool for Mapping Ecosystem Services Trade-Offs on Forested Landscapes. Environ. Res. 2016, 144, 15-26. [CrossRef] [PubMed]

12. Bruins, R.J.; Canfield, T.J.; Duke, C.; Kapustka, L.; Nahlik, A.M.; Schäfer, R.B. Using Ecological Production Functions to Link Ecological Processes to Ecosystem Services. Integr. Environ. Assess. Manag. 2017, 13, 52-61. [CrossRef]

13. Cimon-Morin, J.; Darveau, M.; Poulin, M. Fostering Synergies between Ecosystem Services and Biodiversity in Conservation Planning: A Review. Biol. Conserv. 2013, 166, 144-154. [CrossRef]

14. Maes, J.; Paracchini, M.L.; Zulian, G.; Dunbar, M.B.; Alkemade, R. Synergies and Trade-Offs between Ecosystem Service Supply, Biodiversity, and Habitat Conservation Status in Europe. Biol. Conserv. 2012, 155, 1-12. [CrossRef]

15. Turkelboom, F.; Leone, M.; Jacobs, S.; Kelemen, E.; García-Llorente, M.; Baró, F.; Termansen, M.; Barton, D.N.; Berry, P.; Stange, E.; et al. When We Cannot Have It All: Ecosystem Services Trade-Offs in the Context of Spatial Planning. Ecosyst. Serv. 2018, 29, 566-578. [CrossRef]

16. Maes, J.; Teller, A.; Erhard, M.; Liquete, C.; Braat, L.; Berry, P.M.; Egoh, B.; Puydarrieux, P.; Fiorina, F.; Santos, F.; et al. Mapping and Assessment of Ecosystems and Their Services. An Analytical Framework for Ecosystem Assessments under Action 5 of the EU Biodiversity Strategy to 2020; Technical Report (2013-067); Publications Office of the European Union: Luxembourg, 2013; ISBN 978-92-79-29369-6.

17. Barredo, J.I.; Teller, A.; Bastrup-Birk, A.; Onaindia, M.; de Manuel, B.F.; Madariaga, I.; Rodríguez-Loinaz, G.; Pinho, P.; Nunes, A.; Ramos, A.; et al. Mapping and Assessment of Forest Ecosystems and Their Services: Applications and Guidance for Decision Making in the Framework of MAES; Publications Office of the European Union: Luxembourg, 2016.

18. Crossman, N.D.; Burkhard, B.; Nedkov, S.; Willemen, L.; Petz, K.; Palomo, I.; Drakou, E.G.; Martín-Lopez, B.; McPhearson, T.; Boyanova, K.; et al. A Blueprint for Mapping and Modelling Ecosystem Services. Ecosyst. Serv. 2013, 4, 4-14. [CrossRef]

19. Costa, A.; Madeira, M.; Santos, J.L.; Oliveira, Â. Change and Dynamics in Mediterranean Evergreen Oak Woodlands Landscapes of Southwestern Iberian Peninsula. Landsc. Urban Plan. 2011, 102, 164-176. [CrossRef]

20. Serdoura, F.; Moreira, G.; Almeida, H. Tourism Development in Alentejo Region: A Vehicle for Cultural and Territorial Cohesion. In Proceedings of the Sustainable Architecture and Urban Development, Tripoli, Libya, 3-5 November 2009; Volume 2, pp. 619-634.

21. Mesquita, S.; Capelo, J.; Gama, I.; Marta-Pedroso, C.; Reis, M.; Domingos, T. Using geobotanical tools to map and assess ecosystem services (MAES) in southern Portugal. In Tools for Landscape-Scale Geobotany and Conservation; Geobotany Studies; Pedrotti, F., Box, E.O., Eds.; Springer International Publishing: Cham, Switzerland, 2021; ISBN 978-3-030-74949-1.

22. Chambers, S.A.; Australia, B.V. Birds as Environmental Indicators Review of Literature. 2008. Available online: https: //www.semanticscholar.org/paper/Birds-as-Environmental-Indicators-Review-of-Chambers-Australia/4d43ad5d64e8c6b0 97d3e71aa81071c771cec3f8\#paper-header (accessed on 1 September 2021).

23. Hosmer, D.W., Jr.; Lemeshow, S.; Sturdivant, R.X. Applied Logistic Regression; John Wiley \& Sons: Hoboken, NJ, USA, 2013; Volume 398.

24. Guerra, C.A.; Pinto-Correia, T.; Metzger, M.J. Mapping Soil Erosion Prevention Using an Ecosystem Service Modeling Framework for Integrated Land Management and Policy. Ecosystems 2014, 17, 878-889. [CrossRef]

25. Wischmeier, W.H.; Smith, D.D. Predicting Rainfall Erosion Losses: A Guide to Conservation Planning; US Department of Agriculture, Science and Education Administration: Washington, DC, USA, 1978; No. 537. 
26. Bakker, M.M.; Govers, G.; van Doorn, A.; Quetier, F.; Chouvardas, D.; Rounsevell, M. The Response of Soil Erosion and Sediment Export to Land-Use Change in Four Areas of Europe: The Importance of Landscape Pattern. Geomorphology 2008, 98, $213-226$. [CrossRef]

27. Pimenta, M.T. Directizes Para Aplicação da Equação Universal da Perda de Solo em SIG. 1999. Available online: https:/ /snirh. apambiente.pt/snirh/download/relatorios/factorC_K.pdf (accessed on 1 September 2021).

28. Silva, J.R.C. Fatores da Equaçao Universal de Perdas de Solo e sua conversão para o sistema métrico internacional. Ciên. Agron. Fortaleza 1985, 16, 77-82.

29. IPCC. Guidelines for National Greenhouse Gas Inventories; Prepared by the National Greenhouse Gas Inventories Programme; Eggleston, H.S., Buendia, L., Miwa, K., Ngara, T., Tanabe, K., Eds.; Intergovernmental Panel on Climate Change (IPCC): Hayama, Japan, 2006; ISBN 978-4-88788-032-0.

30. APA. Portuguese National Inventory Report on Greenhouse Gases, 1990-2012; Submitted Under the United Nations Framework Convention on Climate Change and The Kyoto Protocol; Portuguese Environment Agency (APA): Amadora, Portugal, 2014.

31. Jenks, G. The Data Model Concept in Statistical Mapping. Int. Yearb. Cartogr. 1967, 7, 186-190.

32. Rosário, L. Referências Para a Avaliação Do Sequestro de Carbono Orgânico Nos Solos Portugueses, Com Base Na Rede ICP Forest, Biosoil e LQARS; Relatório AFN/SNIERPA inédito; AFN/SNIERPA: Lisboa, Portugal, 2010.

33. Kruskal, W.H.; Wallis, W.A. Use of Ranks in One-Criterion Variance Analysis. J. Am. Stat. Assoc. 1952, 47, 583-621. [CrossRef]

34. Terpstra, T.J. The Asymptotic Normality and Consistency of Kendall's Test against Trend, When Ties Are Present in One Ranking. Indag. Math. Proc. 1952, 55, 327-333. [CrossRef]

35. Jonckheere, A.R. A Distribution-Free k-Sample Test Against Ordered Alternatives. Biometrika 1954, 41, 133-145. [CrossRef]

36. Felipe-Lucia, M.R.; Martín-López, B.; Lavorel, S.; Berraquero-Díaz, L.; Escalera-Reyes, J.; Comín, F.A. Ecosystem Services Flows: Why Stakeholders' Power Relationships Matter. PLoS ONE 2015, 10, e0132232. [CrossRef]

37. Reyers, B.; O’Farrell, P.J.; Cowling, R.M.; Egoh, B.N.; Le Maitre, D.C.; Vlok, J.H.J. Ecosystem Services, Land-Cover Change, and Stakeholders: Finding a Sustainable Foothold for a Semiarid Biodiversity Hotspot. Ecol. Soc. 2009, 14, 38. [CrossRef]

38. Mouchet, M.A.; Rega, C.; Lasseur, R.; Georges, D.; Paracchini, M.-L.; Renaud, J.; Stürck, J.; Schulp, C.J.E.; Verburg, P.H.; Verkerk, P.J.; et al. Ecosystem Service Supply by European Landscapes under Alternative Land-Use and Environmental Policies. Int. J. Biodivers. Sci. Ecosyst. Serv. Manag. 2017, 13, 342-354. [CrossRef]

39. Rodríguez-Echeverry, J.; Echeverría, C.; Oyarzún, C.; Morales, L. Impact of Land-Use Change on Biodiversity and Ecosystem Services in the Chilean Temperate Forests. Landsc. Ecol. 2018, 33, 439-453. [CrossRef]

40. Jones, N.; de Graaff, J.; Rodrigo, I.; Duarte, F. Historical Review of Land Use Changes in Portugal (before and after EU Integration in 1986) and Their Implications for Land Degradation and Conservation, with a Focus on Centro and Alentejo Regions. Appl. Geogr. 2011, 31, 1036-1048. [CrossRef]

41. Morais, T.G.; Silva, C.; Jebari, A.; Álvaro-Fuentes, J.; Domingos, T.; Teixeira, R.F.M. A Proposal for Using Process-Based Soil Models for Land Use Life Cycle Impact Assessment: Application to Alentejo, Portugal. J. Clean. Prod. 2018, 192, 864-876. [CrossRef]

42. Fezzi, C.; Bateman, I.; Askew, T.; Munday, P.; Pascual, U.; Sen, A.; Harwood, A. Valuing Provisioning Ecosystem Services in Agriculture: The Impact of Climate Change on Food Production in the United Kingdom. Environ. Resour. Econ. 2013, 57, 197-214. [CrossRef]

43. Kandziora, M.; Burkhard, B.; Müller, F. Mapping Provisioning Ecosystem Services at the Local Scale Using Data of Varying Spatial and Temporal Resolution. Ecosyst. Serv. 2013, 4, 47-59. [CrossRef]

44. Palma, J.H.N.; Paulo, J.A.; Tomé, M. Carbon Sequestration of Modern Quercus suber L. Silvoarable Agroforestry Systems in Portugal: A YieldSAFE-Based Estimation. Agrofor. Syst. 2014, 88, 791-801. [CrossRef]

45. Campagne, C.S.; Roche, P.; Müller, F.; Burkhard, B. Ten Years of Ecosystem Services Matrix: Review of a (r)Evolution. One Ecosyst. 2020, 5, e51103. [CrossRef]

46. Ribeiro, P.F.; Santos, J.L.; Bugalho, M.N.; Santana, J.; Reino, L.; Beja, P.; Moreira, F. Modelling Farming System Dynamics in High Nature Value Farmland under Policy Change. Agric. Ecosyst. Environ. 2014, 183, 138-144. [CrossRef]

47. Jacobs, S.; Burkhard, B.; Van Daele, T.; Staes, J.; Schneiders, A. 'The Matrix Reloaded': A Review of Expert Knowledge Use for Mapping Ecosystem Services. Ecol. Model. 2015, 295, 21-30. [CrossRef]

48. Perennes, M.; Campagne, C.S.; Müller, F.; Roche, P.; Burkhard, B. Refining the Tiered Approach for Mapping and Assessing Ecosystem Services at the Local Scale: A Case Study in a Rural Landscape in Northern Germany. Land 2020, 9, 348. [CrossRef]

49. European Environment Agency. Mapping and Assessing the Condition of Europe's Ecosystems Progress and Challenges: EEA Contribution to the Implementation of the EU Biodiversity Strategy to 2020; Publications Office of the European Union: Luxembourg, 2016.

50. Swift, M.J.; Izac, A.-M.N.; van Noordwijk, M. Biodiversity and Ecosystem Services in Agricultural Landscapes-Are We Asking the Right Questions? Agric. Ecosyst. Environ. 2004, 104, 113-134. [CrossRef]

51. Czúcz, B.; Haines-Young, R.; Kiss, M.; Bereczki, K.; Kertész, M.; Vári, Á.; Potschin-Young, M.; Arany, I. Ecosystem Service Indicators along the Cascade: How Do Assessment and Mapping Studies Position Their Indicators? Ecol. Indic. 2020, 118, 106729. [CrossRef]

52. Rendon, P.; Steinhoff-Knopp, B.; Saggau, P.; Burkhard, B. Assessment of the Relationships between Agroecosystem Condition and the Ecosystem Service Soil Erosion Regulation in Northern Germany. PLoS ONE 2020, 15, e0234288. [CrossRef] 
53. Daniel, T.C.; Muhar, A.; Arnberger, A.; Aznar, O.; Boyd, J.W.; Chan, K.M.A.; Costanza, R.; Elmqvist, T.; Flint, C.G.; Gobster, P.H.; et al. Contributions of Cultural Services to the Ecosystem Services Agenda. Proc. Natl. Acad. Sci. USA 2012, 109, 8812-8819. [CrossRef]

54. Vrbičanová, G.; Kaisová, D.; Močko, M.; Petrovic, F.; Mederly, P. Mapping Cultural Ecosystem Services Enables Better Informed Nature Protection and Landscape Management. Sustainability 2020, 12, 2138. [CrossRef]

55. Burkhard, B.; Santos-Martin, F.; Nedkov, S.; Maes, J. Burkhard B, Santos-Martin F, Nedkov S, Maes J (2018) An operational framework for integrated Mapping and Assessment of Ecosystems and their Services (MAES). One Ecosystem 2018, 3, e22831. [CrossRef]

56. Smith, A.C.; Harrison, P.A.; Pérez Soba, M.; Archaux, F.; Blicharska, M.; Egoh, B.N.; Erős, T.; Domenech, N.F.; György, Á.I.; Haines-Young, R.; et al. How Natural Capital Delivers Ecosystem Services: A Typology Derived from a Systematic Review. Ecosyst. Serv. 2017, 26, 111-126. [CrossRef]

57. Silveira, A.; Ferrão, J.; Muñoz-Rojas, J.; Pinto-Correia, T.; Guimarães, M.; Schmidt, L. The sustainability of agricultural intensification in the early 21st century:insights from the olive oil production in Alentejo (Southern Portugal). In Changing Societies: Legacies and Challenges. Vol. 3. The Diverse Worlds of Sustainability; Imprensa de Ciências Sociais: Lisboa, Portugal, 2018; pp. 247-275; ISBN 978-972-671-505-4.

58. Pereira, H.M.; Reyers, B.; Watanabe, M.; Bohensky, E.; Foale, S.; Palm, C.; Espaldon, M.V.; Armenteras, D.; Tapia, M.; Rincon, A.; et al. Condition and Trends of Ecosystem Services and Biodiversity; Capistrano, D., Samper, C., Samper, K.C., Lee, M.J., Raudsepp-Hearne, C., Eds.; Island Press: Washington, DC, USA, 2005; Volume 4, pp. 171-203. ISBN 978-1-55963-186-0.

59. Maseyk, F.J.F.; Mackay, A.D.; Possingham, H.P.; Dominati, E.J.; Buckley, Y.M. Managing Natural Capital Stocks for the Provision of Ecosystem Services. Conserv. Lett. 2017, 10, 211-220. [CrossRef]

60. Pinto-Correia, T.; Ribeiro, N.; Sá-Sousa, P. Introducing the Montado, the Cork and Holm Oak Agroforestry System of Southern Portugal. Agrofor. Syst. 2011, 82, 99. [CrossRef]

61. Bugalho, M.; Caldeira, M.; Pereira, J.; Aronson, J.; Pausas, J.G. Mediterranean Cork Oak Savannas Require Human Use to Sustain Biodiversity and Ecosystem Services. Front. Ecol. Environ. 2011, 9, 278. [CrossRef]

62. Esgalhado, C.; Guimarães, H.; Debolini, M.; Guiomar, N.; Lardon, S.; Ferraz de Oliveira, I. A Holistic Approach to Land System Dynamics-The Monfurado Case in Alentejo, Portugal. Land Use Policy 2020, 95, 104607. [CrossRef]

63. Laporta, L.; Domingos, T.; Marta-Pedroso, C. It's a Keeper: Valuing the Carbon Storage Capacity of Agroforestry Ecosystems in the Context of CAP Eco-Schemes. Land Use Policy 2021, 109, 105712. [CrossRef] 